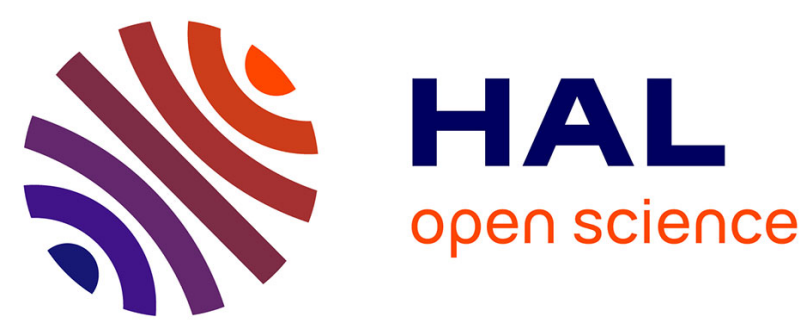

\title{
Trace element geochemistry of the 1991 Mt. Pinatubo silicic melts, Philippines: Implications for ore-forming potential of adakitic magmatism.
}

\author{
Anastassia Yu Borisova, Michel Pichavant, Mireille Polvé, Michael \\ Wiedenbeck, Rémi Freydier, Frédéric Candaudap
}

\section{To cite this version:}

Anastassia Yu Borisova, Michel Pichavant, Mireille Polvé, Michael Wiedenbeck, Rémi Freydier, et al.. Trace element geochemistry of the $1991 \mathrm{Mt}$. Pinatubo silicic melts, Philippines: Implications for ore-forming potential of adakitic magmatism.. Geochimica et Cosmochimica Acta, 2006, 70, pp.14, 3702-3716. 10.1016/j.gca.2006.04.030 . hal-00081782

\section{HAL Id: hal-00081782 \\ https://hal-insu.archives-ouvertes.fr/hal-00081782}

Submitted on 7 Aug 2006

HAL is a multi-disciplinary open access archive for the deposit and dissemination of scientific research documents, whether they are published or not. The documents may come from teaching and research institutions in France or abroad, or from public or private research centers.
L'archive ouverte pluridisciplinaire HAL, est destinée au dépôt et à la diffusion de documents scientifiques de niveau recherche, publiés ou non, émanant des établissements d'enseignement et de recherche français ou étrangers, des laboratoires publics ou privés. 


\title{
Trace element geochemistry of the 1991 Mt. Pinatubo silicic melts, Philippines: Implications for ore-forming potential of adakitic magmatism
}

\author{
Anastassia Yu. Borisova ${ }^{a}, \underline{b}$, Michel Pichavant ${ }^{\underline{c}}$, Mireille Polvéa $^{\underline{a}}$, Michael Wiedenbeck ${ }^{\underline{d}}$, \\ Remi Freydierra and Frédéric Candaudap ${ }^{\underline{a}}$
}

${ }^{a}$ Laboratoire des Mécanismes et Transferts en Géologie, LMTG - UMR 5563 - OMP CNRS, 14 Avenue E. Belin, 31400 Toulouse, France

${ }^{b}$ Vernadsky Institutes of Geochemistry and Analytical Chemistry, RAS Kosiguin str., 19, 117975 Moscow, Russia

'Institut des Sciences de la Terre d'Orléans, CNRS-ISTO, 1A, rue de la Férollerie 45071

Orléans, Cedex 2, France

${ }^{\mathrm{d}}$ GeoForschungsZentrum Potsdam, Telegrafenberg, D14473 Potsdam, Germany

\begin{abstract}
The dacite pumice erupted from Mt. Pinatubo on June 15, 1991 (whole-rock, rhyolitic groundmass glasses and homogenized melt inclusions) has been analyzed using inductively coupled plasma-mass spectrometry (ICP-MS), nanosecond and femtosecond laser ablation ICP-MS and secondary ion mass spectrometry (SIMS) to evaluate its ore-forming potential. Data suggest that adakite magmas are metal-rich and concentrate ore metals during magmatic differentiation. Sulfides segregate in limited amounts under the hydrous, oxidizing conditions typical of adakitic magmas resulting in incompatible behavior for $\mathrm{Au}$ (6-22 ppb), $\mathrm{Cu}$ (26$77 \mathrm{ppm}$ ), and $\mathrm{Pb}, \mathrm{Mo}, \mathrm{As}$, and $\mathrm{Sb}$ in melts of dacitic to rhyolitic compositions. Metal transfer from this adakite magma to the coexisting aqueous phase was favored by the peraluminous composition of the rhyolitic melt and high aqueous chloride concentrations. Mass balance calculations suggest that the pre-eruptive aqueous phase could have extracted a minimum of $100 \mathrm{t} \mathrm{Au}$ and $5 \times 10^{5} \mathrm{t} \mathrm{Cu}$ from the Mt. Pinatubo magma. Our data suggest that intrusives having adakitic signatures are genetically associated with $\mathrm{Au}-\mathrm{Cu}$ and $\mathrm{Cu}-\mathrm{Mo}$ mineralization, auriferous porphyry copper deposits, and epithermal gold veins. $\mathrm{High} \mathrm{H}_{2} \mathrm{O}, \mathrm{Cl}, \mathrm{Sr} / \mathrm{Y}, \mathrm{Pb} / \mathrm{Ce}$, $\mathrm{Mo} / \mathrm{Ce}, \mathrm{As} / \mathrm{Ce}$ and $\mathrm{Sb} / \mathrm{Ce}$ in Mt. Pinatubo melts reflect the contribution of deep fluids derived from subducted sediments and altered MORBs in the dacite genesis. The slab-derived fluids carrying mobile elements are likely responsible for the enrichment of adakite magmas in gold, associated metals and $\mathrm{H}_{2} \mathrm{O}$, and may explain the exceptional ore-forming potential of adakite magmatism.
\end{abstract}

\section{Introduction}

Adakites are silicic- to intermediate-composition magmas which are commonly believed to be generated by partial melting of subducted oceanic crust (e.g., Defant and Drummond, 1990 and Sen and Dunn, 1994), although other models, such as high-pressure fractionation of hydrous basaltic magmas, have also been proposed recently for their genesis (e.g., Prouteau and Scaillet, 2003). Adakitic magmas are typically enriched in $\mathrm{H}_{2} \mathrm{O}$ (Prouteau et al., 1999) and lithophile elements such as Al, Na, Sr and LREE (Drummond and Defant, 1990 and Peacock et al., 1994). Intrusives with an adakitic signature are spatially and temporally and, perhaps, genetically associated with $\mathrm{Au}-\mathrm{Cu}$ and $\mathrm{Cu}-\mathrm{Mo}$ mineralization, auriferous porphyry 
copper deposits, and epithermal gold veins (e.g., White et al., 1995, Sajona and Maury, 1998, González-Partida et al., 2003, Reich et al., 2003, Qu et al., 2004 and Whalen et al., 2004). However, the petrological and geochemical mechanisms which are responsible for the systematic relationship between adakitic magmatic rocks and gold and associated metals concentrations remain unclear (Thiéblemont et al., 1997 and Mungall, 2002). Understanding the mechanisms that control the links between adakitic magmas and $\mathrm{Au}-\mathrm{Cu}$ (and $\mathrm{Cu}-\mathrm{Mo}$ ) mineralization is important both for metallogenic models and associated metals exploration strategies.

In this study, we assume as a working hypothesis that adakite magmas are enriched in $\mathrm{Au}$ (typically 3-7 ppb) in comparison with non-adakitic (typically $<3 \mathrm{ppb),} \mathrm{silicic-} \mathrm{to}$ intermediate-composition magmas (Polvé et al., 2003, Polvé et al., 2004 and Jégo et al., 2004). Thus, adakites are able to pre-concentrate $\mathrm{Au}$ (with $\mathrm{Cu}$ and associated metals) through magmatic processes. The systematic association between adakites and $\mathrm{Au}-\mathrm{Cu}$ mineralization (e.g., Thiéblemont et al., 1997) would thus result from the combination of magmatic preconcentration mechanisms with favorable hydrothermal transport and deposition processes. To investigate the magmatic pre-concentration mechanisms, we have carried out an analytical study of a typical example of adakite, the dacite pumice erupted on June 15, 1991, by the Mt. Pinatubo volcano, Philippines (Bernard et al., 1996, Prouteau et al., 1999 and Prouteau and Scaillet, 2003).

The Mt. Pinatubo dacite is strongly enriched in sulfur (e.g., Bernard et al., 1996), $\mathrm{Cu}$ and $\mathrm{Zn}$ (Pallister et al., 1996). The $\delta^{34} \mathrm{~S}$ values for the 1991 dacite are similar to those of $\mathrm{Cu}-\mathrm{Au}$ porphyry deposits of Miocene to Pliocene ages surrounding Mt. Pinatubo (Imai et al., 1993 and Imai et al., 1996). Located south of the North Luzon $\mathrm{Au}-\mathrm{Cu}$ province of MiocenePliocene age, Mt. Pinatubo is only $19 \mathrm{~km}$ north of the $2.7 \mathrm{Ma}$ Dizon major $\mathrm{Cu}-\mathrm{Au}$ porhyry copper deposit (Malihan, 1987), and several porphyry-type prospects are known in its immediate vicinity (Imai et al., 1996; Fig. 1). Therefore, metal concentration processes in the 1991 Mt. Pinatubo magma may be representative of those occurring in the North to WestCentral Luzon $\mathrm{Au}-\mathrm{Cu}$ district.

The Mt. Pinatubo dacite preserves rapidly quenched silicate glasses and sulfides, allowing metal concentrations to be determined at different stages of the magmatic evolution. Previous work on melt, crystal and fluid inclusions in mineral phases of the Mt. Pinatubo white dacite pumices (Westrich and Gerlach, 1992, Gerlach et al., 1996, Pasteris et al., 1996, Rutherford and Devine, 1996 and Borisova et al., 2005), together with experimental data (Rutherford and Devine, 1996, Scaillet and Evans, 1999, Prouteau et al., 1999 and Prouteau and Scaillet, 2003) have constrained the conditions of genesis, high-pressure evolution, and pre-eruptive crystallization and degassing of the dacite magma. The chalcophile trace element chemistry of sulfide phases in the Mt. Pinatubo dacites, andesites and basalts has been investigated by Fournelle et al., 1996, Hattori, 1993 and Hattori, 1996. However, there are as yet no data on ore metal concentrations for the silicate glasses. Here, we present an in situ microanalytical study of volatiles $\left(\mathrm{H}_{2} \mathrm{O}\right)$ and ore metals $(\mathrm{Cu}, \mathrm{Zn}, \mathrm{Mo}$ and $\mathrm{Pb})$ in homogenized melt inclusions using secondary ion mass spectrometry (SIMS). These data are combined with microanalyses of trace elements (including $\mathrm{Au}$ ) in matrix glasses using nanosecond and femtosecond laser ablation ICP-MS, and with analyses of the host dacite pumice using ICP-MS. The data reported here constrain the trace element chemistry of the Mt. Pinatubo melts and provide new insights into mechanisms of metal pre-concentration during adakitic magma genesis and differentiation. 


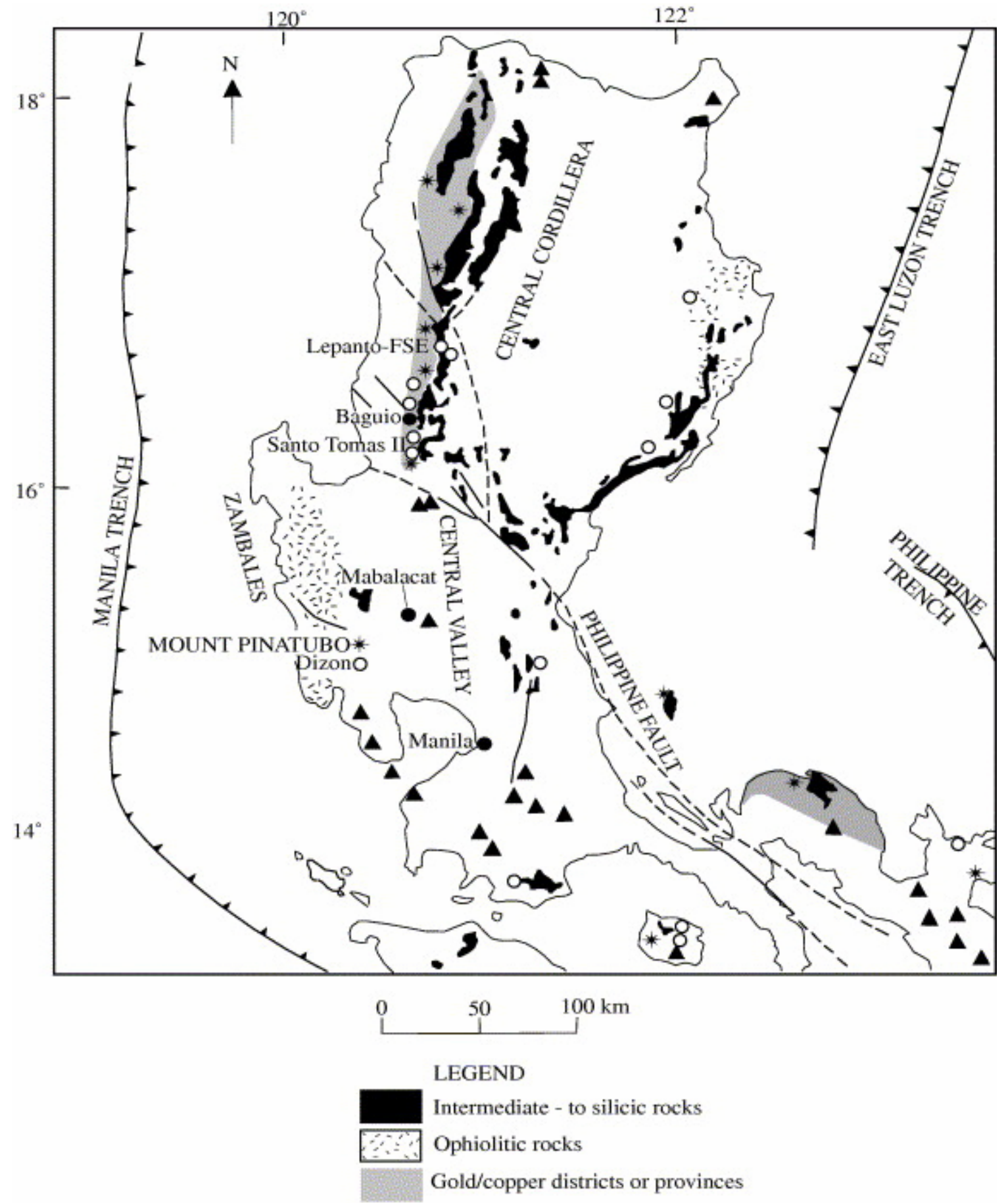

A Quarternary volcano

- Major porhyry copper deposits

* Adakite and adakite-like rocks

Faults

Fig. 1. Geologic map showing the location of quaternary volcanoes, major porphyry copper deposits, Cenozoic intermediate to silicic intrusives, and ophiolitic rocks at Luzon, Philippines (adopted after Imai et al., 1996 and modified after Sajona and Maury, 1998). Tertiary intermediate to felsic intrusives and ophiolitic rocks are also shown. Adakite and adakite-like rocks related to gold-copper districts or provinces are shown according to Sajona and Maury (1998). 
The Mt. Pinatubo dacite preserves rapidly quenched silicate glasses and sulfides, allowing metal concentrations to be determined at different stages of the magmatic evolution. Previous work on melt, crystal and fluid inclusions in mineral phases of the Mt. Pinatubo white dacite pumices (Westrich and Gerlach, 1992, Gerlach et al., 1996, Pasteris et al., 1996, Rutherford and Devine, 1996 and Borisova et al., 2005), together with experimental data (Rutherford and Devine, 1996, Scaillet and Evans, 1999, Prouteau et al., 1999 and Prouteau and Scaillet, 2003) have constrained the conditions of genesis, high-pressure evolution, and pre-eruptive crystallization and degassing of the dacite magma. The chalcophile trace element chemistry of sulfide phases in the Mt. Pinatubo dacites, andesites and basalts has been investigated by Fournelle et al., 1996, Hattori, 1993 and Hattori, 1996. However, there are as yet no data on ore metal concentrations for the silicate glasses. Here, we present an in situ microanalytical study of volatiles $\left(\mathrm{H}_{2} \mathrm{O}\right)$ and ore metals $(\mathrm{Cu}, \mathrm{Zn}$, Mo and $\mathrm{Pb})$ in homogenized melt inclusions using secondary ion mass spectrometry (SIMS). These data are combined with microanalyses of trace elements (including $\mathrm{Au}$ ) in matrix glasses using nanosecond and femtosecond laser ablation ICP-MS, and with analyses of the host dacite pumice using ICP-MS. The data reported here constrain the trace element chemistry of the Mt. Pinatubo melts and provide new insights into mechanisms of metal pre-concentration during adakitic magma genesis and differentiation.

\section{Analytical techniques}

\subsection{Melt inclusion and matrix preparation for analyses}

Primary melt inclusions in quartz were completely or partially homogenized at $760{ }^{\circ} \mathrm{C}$ and $200 \mathrm{MPa}$. Detailed descriptions of melt inclusion types before and after homogenization experiments and of the experimental procedures are given in Borisova et al. (2005) along with major element data on the included glass and crystalline phases. The experimental run duration of 20-24 h was chosen according to the diffusion rates of $\mathrm{H}_{2} \mathrm{O}$ and $\mathrm{CO}_{2}$ in silicic glasses (Watson, 1994) to produce homogeneous glasses in the melt inclusions. The melt inclusions range in size from 30 to $150 \mu \mathrm{m}$ and contain homogeneous glasses; only inclusions with minor or no bubble(s) were selected (Fig. 2). After the homogenization experiment, quartz grains were mounted in epoxy (Teflon slides, 1 -in. diameter) and polished by hand with 3-, 1- and 0.5- $\mu \mathrm{m}$ diamond pastes (Hyprez, Liquid Diamond) until the melt inclusions were exposed at the surface (Borisova et al., 2005). To avoid possible surface contamination with metals like $\mathrm{Au}, \mathrm{Cu}, \mathrm{Zn}$, As and $\mathrm{Sb}$, we polished quartz grains with pure diamond pastes. Thick sections $(300 \mu \mathrm{m})$ of dacite pumices and $<0.5$ - $\mathrm{mm}$ pieces of matrix glasses were epoxymounted and polished with precautions as well to avoid surface contamination with gold and base metals. 

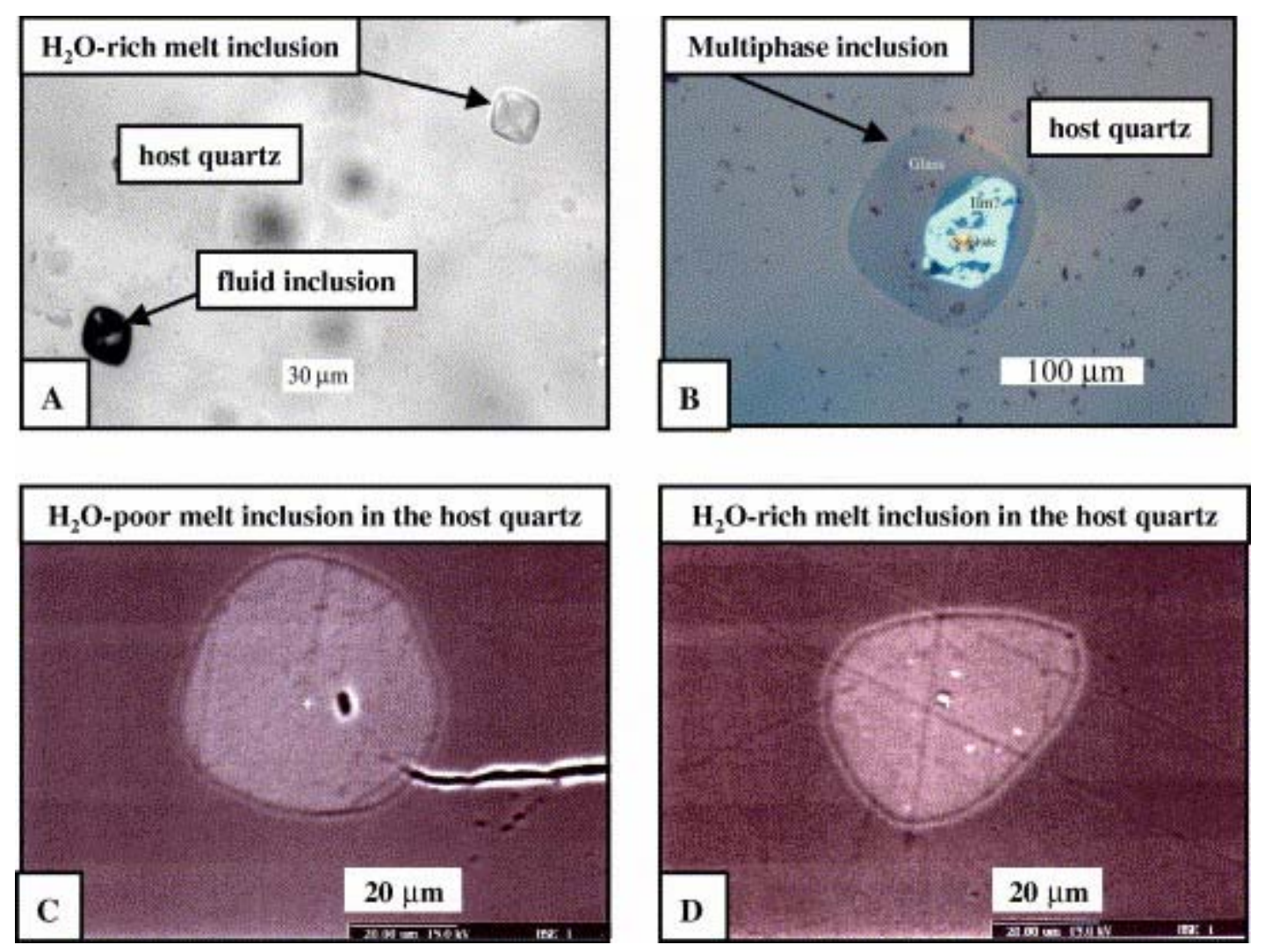

Fig. 2. Photomicrographs of inclusions after homogenization experiment: (A) Assemblage of primary fluid inclusion, at present empty (left) and primary melt inclusion (right) homogenized at $780{ }^{\circ} \mathrm{C}$ and $185 \mathrm{MPa}$, providing evidence for two-phase entrapment of coexisting melt and supercritical fluid under pre-eruptive conditions (in transmitted light); (B) Multi-phase inclusion after experiment at $780{ }^{\circ} \mathrm{C}$ and $185 \mathrm{MPa}$ containing sulfide globule (center) entrapped in ilmenite and enclosed in rhyolitic melt (in reflected light); (C) Decrepitated $\left(\mathrm{H}_{2} \mathrm{O}\right.$-poor) melt inclusion (in back-scattered electron mode); (D) Stable $\left(\mathrm{H}_{2} \mathrm{O}\right.$-rich) melt inclusion homogenized at $760{ }^{\circ} \mathrm{C}$ and $200 \mathrm{MPa}$ (in back-scattered electron mode).

\subsection{Analytical techniques}

Major elements concentrations in the inclusion glasses were determined by electron microprobe analysis (EMPA) with a fully automated CAMECA SX-100 in GeoForschungsZentrum in Potsdam, Germany. X-ray were excited with a 15-kV accelerating voltage and $10 \mathrm{nA}$ beam current. The acquisition time for major elements ( $\mathrm{Si}, \mathrm{Ti} \mathrm{Al}, \mathrm{Fe}, \mathrm{Mg}$, $\mathrm{Ca}, \mathrm{Na}$ and $\mathrm{K})$ was $20 \mathrm{~s} / \mathrm{element}$. A defocused beam $\left(\sim 15 \mu \mathrm{m}^{2}\right)$ was used to minimize $\mathrm{Na}$ loss. The following EMPA standards were used: albite $(\mathrm{Na})$, periclase $(\mathrm{Mg})$, wollastonite $(\mathrm{Si}$, $\mathrm{Ca}), \mathrm{Fe}_{2} \mathrm{O}_{3}(\mathrm{Fe})$, rutile (Ti) and orthoclase ( $\left.\mathrm{Al}, \mathrm{K}\right)$. Groundmass glasses and sulphide analyses were performed at the Laboratoire des Mécanismes et Transferts en Géologie (Toulouse, France) using a CAMECA SX50 microprobe with SAMx automation. The operating conditions were $15 \mathrm{kV}$ of accelerating voltage and $10 \mathrm{nA}$ of beam current for glasses, and $25 \mathrm{kV}$ of accelerating voltage and $20 \mathrm{nA}$ of beam current for sulphides. Standards were synthetic compounds and natural minerals. Following electron microprobe analysis, the epoxy mounts were slightly polished with pure $\mathrm{Al}_{2} \mathrm{O}_{3}$ powder $(0.3-\mu \mathrm{m})$ to remove the carbon coating, cleaned in ethanol (Normapur grade), dried at $80^{\circ} \mathrm{C}$ for $1 \mathrm{~h}$ to remove surface water, and then gold coated for secondary ion mass spectrometric (SIMS) analyses.

SIMS analyses of $\mathrm{H}$ and selected trace elements $\mathrm{Cu}, \mathrm{Zn}, \mathrm{Pb}, \mathrm{Mo}, \mathrm{La}, \mathrm{Ce}$ and $\mathrm{Pr}$ were performed using the CAMECA ims $6 \mathrm{f}$ ion probe in GeoForschungsZentrum, Potsdam. To 
eliminate any possible surface contamination and to remove the 35-nm gold coat, each analysis spot was pre-sputtered for 3 min with a $12-\mathrm{nA}^{16} \mathrm{O}^{-}$beam which was rastered over a $25 \times 25 \mu \mathrm{m}$ area. The actual analyses recorded the intensities on the ${ }^{1} \mathrm{H}^{+},{ }^{30} \mathrm{Si}^{+},{ }^{64} \mathrm{Zn}^{+},{ }^{65} \mathrm{Cu}^{+}$, ${ }^{139} \mathrm{La}^{+},{ }^{140} \mathrm{Ce}^{+},{ }^{141} \mathrm{Pr}^{+},{ }^{98} \mathrm{Mo}^{+}$and ${ }^{208} \mathrm{~Pb}^{+}$peaks using a primary beam intensity of $8 \mathrm{nA}$ focused to a $\sim 25-\mu \mathrm{m}$ diameter spot on the sample surface. A $120-\mathrm{V}$ offset was applied to the nominally $10 \mathrm{kV}$, in conjunction with a $50-\mathrm{V}$ energy bandpass, in order to suppress isobaric interferences (e.g., Hervig, 1996). Counting times for each cycle were: ${ }^{1} \mathrm{H}^{+}(4 \mathrm{~s}),{ }^{30} \mathrm{Si}^{+}(2 \mathrm{~s})$, ${ }^{44} \mathrm{Ca}^{+}(2 \mathrm{~s}),{ }^{64} \mathrm{Zn}^{+}(8 \mathrm{~s}),{ }^{65} \mathrm{Cu}^{+}(8 \mathrm{~s}),{ }^{98} \mathrm{Mo}^{+}(30 \mathrm{~s}),{ }^{139} \mathrm{La}^{+}(8 \mathrm{~s}),{ }^{140} \mathrm{Ce}^{+}(15 \mathrm{~s}),{ }^{141} \mathrm{Pr}^{+}(15 \mathrm{~s})$ and ${ }^{208} \mathrm{~Pb}^{+}(30 \mathrm{~s})$. Twenty integration cycles of this peak-stepping sequence thus yielded a total analysis time of $46 \mathrm{~min}$. The host quartz grains were used to estimate the water background which was consistently below $0.1 \mathrm{wt} \% \mathrm{H}_{2} \mathrm{O}$. The count rates from ${ }^{1} \mathrm{H}^{+},{ }^{64} \mathrm{Zn}^{+},{ }^{65} \mathrm{Cu}^{+},{ }^{98} \mathrm{Mo}^{+}$, ${ }^{139} \mathrm{La}^{+},{ }^{140} \mathrm{Ce}^{+},{ }^{141} \mathrm{Pr}^{+}$and ${ }^{208} \mathrm{~Pb}^{+}$were normalized to ${ }^{30} \mathrm{Si}^{+}$. The intensities of either ${ }^{1} \mathrm{H} /{ }^{30} \mathrm{Si}$, ${ }^{64} \mathrm{Zn} /{ }^{30} \mathrm{Si}$ or ${ }^{65} \mathrm{Cu} /{ }^{30} \mathrm{Si}$ signals in some glasses decayed and attained constant values only after the first 10 cycles of data collection; in this case only the data obtained in the last 5-10 cycles were used to calculate the element abundances (Table 1). The concentrations of water and trace elements in the glass samples were determined by SIMS using calibrations with reference glasses of known concentrations (see electronic annex, Table EA1). For $\mathrm{H}^{+}$a calibration curve was established from the nominally anhydrous NIST SRM 610 glass, a series of hydrated glasses prepared from NIST 610 and a series of hydrated andesitic glasses (see Wiedenbeck et al., 2001 and Koepke and Behrens, 2001). For the trace elements calibration we used anhydrous glasses, such as NIST SRM 610 glass, the above mentioned synthetic andesitic glass, and natural rhyolitic obsidian Macusani (or MAC3, electronic annex, Table EA1). All these reference samples were checked for homogeneity with respect to trace element contents by LA-ICP-MS, and trace element concentrations in Macusani glasses were re-analyzed by ICP-MS (electronic annex, Table EA1). Calibration curves were prepared by plotting the measured $\mathrm{M}^{+} /{ }^{30} \mathrm{Si}^{+}$ratios of standards against their trace element concentrations, normalizing to silicon concentrations (in ppm) known or obtained by EMPA (see electronic annex, Fig. EA1-EA8). We did not detect any dependence of the relative sensitivity factors of ${ }^{65} \mathrm{Cu} /{ }^{30} \mathrm{Si},{ }^{98} \mathrm{Mo} /{ }^{30} \mathrm{Si},{ }^{139} \mathrm{La} /{ }^{30} \mathrm{Si},{ }^{140} \mathrm{Ce} /{ }^{30} \mathrm{Si}$ and ${ }^{141} \mathrm{Pr} /{ }^{30} \mathrm{Si}$ for $\mathrm{Cu}$, Mo and LREE as a function of water content, whereas some decrease in the relative sensitivity factors of ${ }^{64} \mathrm{Zn} /{ }^{30} \mathrm{Si}$ and ${ }^{208} \mathrm{~Pb} /{ }^{30} \mathrm{Si}$ was observed in the most hydrated glasses. We have used the observed external precision (for 37 reference samples combined) to evaluate the precision of our analyses: for hydrous glasses this corresponds to $\pm 5-10 \%$ of the value for low $\mathrm{H}_{2} \mathrm{O}$ concentrations $(<3.87 \mathrm{wt} \%)$ and to $\pm 15-20 \%$ for high $\mathrm{H}_{2} \mathrm{O}$ concentrations samples $(\gg$ $3.87 \mathrm{wt} \%)$ (electronic annex, Table EA1). 

Table 1. : Major and trace element composition of two types of melt inclusions in quartz, matrix glasses and pre-eruptive and degassing rhyolitic melts

\begin{tabular}{|c|c|c|c|c|c|c|c|c|c|}
\hline Inclusion: & Hom2a:2a & Hom2a:2b & Hom2a:4a & Hom2a:4c & Hom2a:6b & Hom2a:6c & Hom2a:8a & Hom2a:10a & Hom2a:11c \\
\hline Features: & $\mathrm{H}_{2} \mathrm{O}$-rich & $\mathrm{H}_{2} \mathrm{O}$-poor & $\mathrm{H}_{2} \mathrm{O}$-rich & $\mathrm{H}_{2} \mathrm{O}$-poor & $\mathrm{H}_{2} \mathrm{O}$-rich & $\mathrm{H}_{2} \mathrm{O}$-rich & $\mathrm{H}_{2} \mathrm{O}$-poor & $\mathbf{H}_{2} \mathbf{O}$-poor & $\mathrm{H}_{2} \mathrm{O}$-rich \\
\hline $\mathrm{SiO}_{2}(\mathrm{wt} \%)_{\mathrm{EMPA}}$ & 73.95 & 77.66 & 75.46 & 77.98 & 74.87 & 75.74 & 78.33 & 77.94 & 75.21 \\
\hline $\mathrm{TiO}_{2}$ & 0.11 & 0.11 & 0.07 & 0.09 & 0.12 & 0.14 & 0.13 & 0.08 & 0.11 \\
\hline $\mathrm{Al}_{2} \mathrm{O}_{3}$ & 11.82 & 13.19 & 11.84 & 13.22 & 11.97 & 11.85 & 13.35 & 13.26 & 12.05 \\
\hline $\mathrm{FeO}^{\mathrm{c}}$ & 0.71 & 0.76 & 0.58 & 0.72 & 0.59 & 0.55 & 0.83 & 0.64 & 0.67 \\
\hline $\mathrm{MgO}$ & 0.17 & 0.24 & 0.15 & 0.18 & 0.16 & 0.16 & 0.23 & 0.15 & 0.19 \\
\hline $\mathrm{CaO}$ & 1.02 & 1.21 & 1.02 & 1.22 & 1.11 & 1.08 & 1.24 & 1.11 & 1.03 \\
\hline $\mathrm{Na}_{2} \mathrm{O}$ & 3.23 & 3.70 & 2.97 & 3.63 & 2.41 & 2.01 & 3.74 & 3.92 & 3.47 \\
\hline $\mathrm{K}_{2} \mathrm{O}$ & 2.58 & 2.80 & 2.53 & 2.83 & 2.52 & 2.26 & 2.78 & 2.84 & 2.54 \\
\hline Sum & 93.59 & 99.68 & 94.62 & 99.87 & 93.74 & 93.80 & 100.63 & 99.95 & 95.27 \\
\hline $\mathrm{H}_{2} \mathrm{O}(\mathrm{wt} \%)_{\mathrm{EMPA}}{ }^{\mathrm{a}}$ & 8.79 & 3.88 & 6.73 & n.a. & n.a. & n.a. & 0.88 & 1.24 & 7.11 \\
\hline $\mathrm{H}_{2} \mathrm{O}(\mathrm{wt} \%)_{\text {SIMS }}$ & 8.67 & 2.84 & 7.03 & 0.10 & 8.74 & $4.29^{\mathrm{d}}$ & 0.10 & 1.06 & 8.31 \\
\hline $\mathrm{Zn}(\mathrm{ppm})_{\mathrm{SIMS}}$ & 51 & 94 & d.l. & 122 & 51 & 16 & 137 & 101 & 55 \\
\hline $\mathrm{Cu}$ & 110 & 118 & d.l. & 89 & 100 & d.l. & 47 & d.l. & d.l. \\
\hline Mo & 2.0 & 2.0 & 2.0 & 2.1 & 1.8 & 1.5 & 2.0 & 2.1 & 1.9 \\
\hline
\end{tabular}




\begin{tabular}{|c|c|c|c|c|c|c|c|c|c|c|}
\hline Inclusion: & Hom2a:2a & Hom2a:2b & Hom2a:4a & Hom2a:4c & Hom2a:6b & Hom2a:6c & Hom2a:8a & Hom2a:10a & Hom2a:11c & \\
\hline Features: & $\mathrm{H}_{2} \mathrm{O}$-rich & $\mathrm{H}_{2} \mathrm{O}$-poor & $\mathrm{H}_{2} \mathrm{O}$-rich & $\mathrm{H}_{2} \mathrm{O}$-poor & $\mathrm{H}_{2} \mathrm{O}$-rich & $\mathrm{H}_{2} \mathrm{O}$-rich & $\mathrm{H}_{2} \mathrm{O}$-poor & $\mathrm{H}_{2} \mathrm{O}$-poor & $\mathrm{H}_{2} \mathrm{O}$-rich & \\
\hline $\mathrm{La}$ & 16 & 17 & 17 & 19 & 15 & 11 & 22 & 20 & 14 & \\
\hline $\mathrm{Ce}$ & 17 & 18 & 19 & 22 & 16 & 8 & 26 & 23 & 14 & \\
\hline $\operatorname{Pr}$ & 1.5 & 1.6 & 1.6 & 1.9 & 1.3 & 0.7 & 2.4 & 2.1 & 1.1 & \\
\hline $\mathrm{Pb}$ & d. $1 . \stackrel{\mathrm{c}}{ }$ & d.l. & d.l. & 16 & d.l. & d.l. & 14 & 19 & d.l. & \\
\hline Inclusion: & Hom $2 \mathrm{ax} 12 \mathrm{a}$ & Hom $2 a x 13 a$ & Hom $2 a x 14 a$ & Hom 2b:1c & Hom $2 b: 2 d$ & Hom $2 \mathrm{bx} 1 \mathrm{a}$ & \multicolumn{2}{|c|}{ Rhyolitic melt ${ }^{\mathrm{f}}$} & \multicolumn{2}{|l|}{ Matrix glass $^{\mathrm{g}}$} \\
\hline Features: & $\mathrm{H}_{2} \mathrm{O}$-poor & $\mathrm{H}_{2} \mathrm{O}$-poor & $\mathrm{H}_{2} \mathrm{O}$-poor & $\mathrm{H}_{2} \mathrm{O}$-rich & $\mathrm{H}_{2} \mathrm{O}$-rich & $\mathrm{H}_{2} \mathrm{O}$-poor & Pre-eruptive & Degassing & $\mathrm{Nn}$ & $F m$ \\
\hline $\mathrm{SiO}_{2}(\mathrm{wt} \%)_{\mathrm{EMPA}}$ & 79.54 & 76.73 & 78.65 & 74.94 & 74.61 & 75.29 & 79.7 & 78.1 & & $77.20 \pm 0.53$ \\
\hline $\mathrm{TiO}_{2}$ & 0.10 & 0.07 & 0.12 & 0.11 & 0.12 & 0.07 & 0.09 & 0.11 & & $0.14 \pm 0.08$ \\
\hline $\mathrm{Al}_{2} \mathrm{O}_{3}$ & 13.31 & 12.65 & 13.16 & 11.68 & 11.91 & 12.64 & 12.0 & 12.7 & & $12.66 \pm 0.14$ \\
\hline $\mathrm{FeO}^{\mathrm{c}}$ & 0.33 & 0.67 & 0.66 & 0.64 & 0.49 & 0.67 & 0.60 & 0.72 & & $1.18 \pm 0.35$ \\
\hline $\mathrm{MgO}$ & 0.03 & 0.15 & 0.18 & 0.14 & 0.15 & 0.14 & 0.15 & 0.18 & & $0.13 \pm 0.05$ \\
\hline $\mathrm{CaO}$ & 1.17 & 1.09 & 1.15 & 1.13 & 1.05 & 1.11 & 1.03 & 1.13 & & $1.22 \pm 0.08$ \\
\hline $\mathrm{Na}_{2} \mathrm{O}$ & 3.66 & 3.91 & 3.59 & 2.59 & 2.61 & 3.77 & 3.4 & 3.7 & & $3.82 \pm 0.19$ \\
\hline $\mathrm{K}_{2} \mathrm{O}$ & 2.99 & 2.79 & 2.87 & 2.42 & 2.64 & 2.81 & 2.9 & 3.2 & & $3.05 \pm 0.08$ \\
\hline Sum & 101.13 & 98.06 & 100.37 & 93.67 & 93.56 & 96.50 & 99.9 & 99.9 & & 99.41 \\
\hline
\end{tabular}




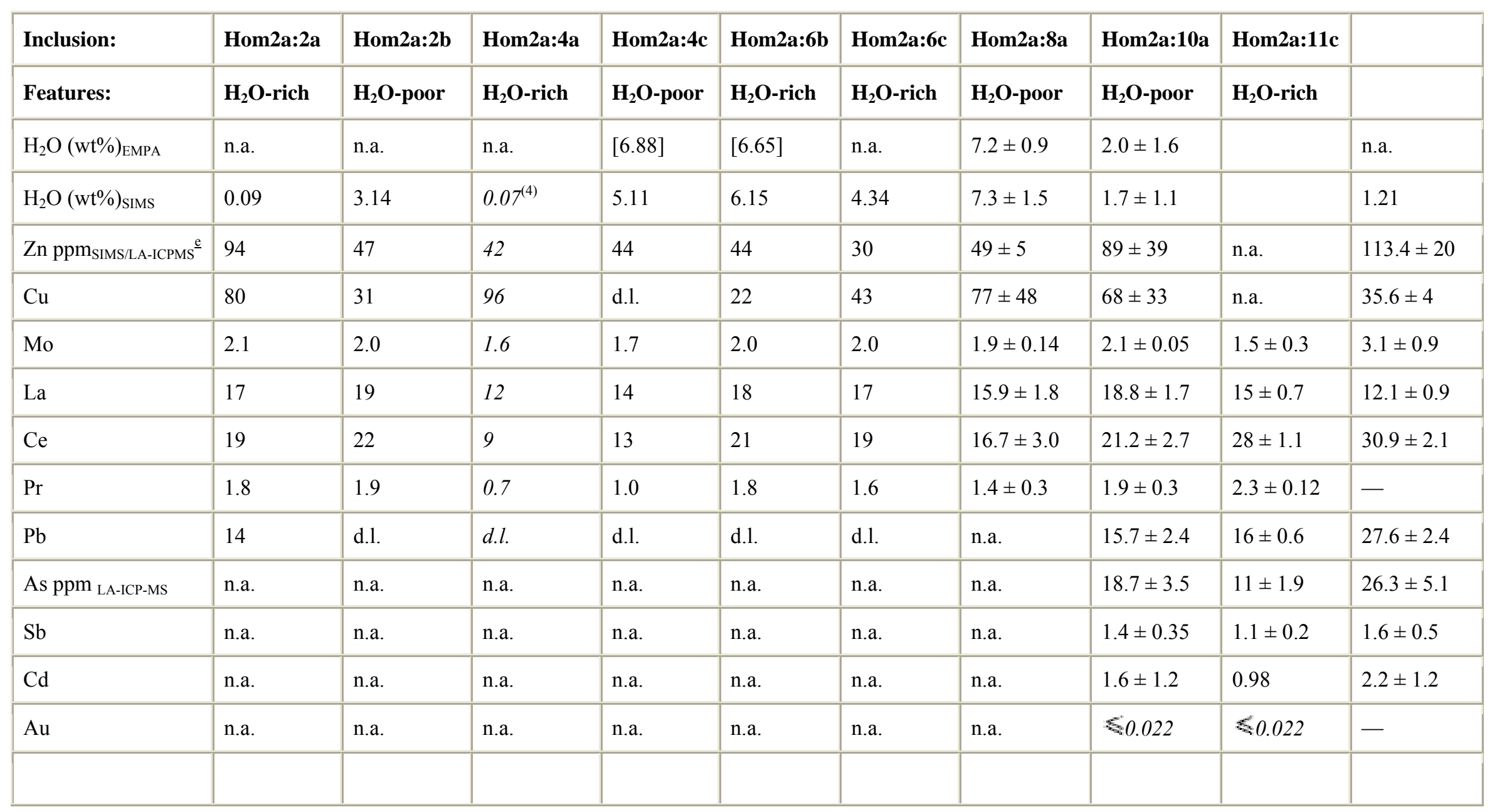

${ }^{\mathrm{a}} \mathrm{H}_{2} \mathrm{O}(\mathrm{wt} \%)_{\text {EMPA }}$ concentrations are determined by EMPA (Borisova et al., 2005) in $\mathrm{H}_{2} \mathrm{O}$-rich $\left(\mathrm{H}_{2} \mathrm{O} \geqslant 5\right.$ wt $\left.\%\right)$ and $\mathrm{H}_{2} \mathrm{O}$-poor $\left(\mathrm{H}_{2} \mathrm{O}<5\right.$ wt $\left.\%\right)$ glasses of melt inclusions. ${ }^{\mathrm{b}} \mathrm{H}_{2} \mathrm{O}(\mathrm{wt} \%)_{\text {SIMS }}$ and trace element contents are determined by SIMS (this work); major element analyses of melt inclusions by EMPA were performed in GFZ.

${ }^{\mathrm{c}}$ n.a., values are not available; d.l., values are below detection limit due to either strong drift or drop in ${ }^{65} \mathrm{Cu} /{ }^{\beta 0} \mathrm{Si}$, ${ }^{64} \mathrm{Zn} /{ }^{30} \mathrm{Si}$ signals and either strong variations in ${ }^{208} \mathrm{~Pb} /{ }^{30} \mathrm{Si}$ signals upon an analysis.

${ }^{\mathrm{d}}$ Low water and trace element concentrations (italized) are due to an excess of the host quartz during the SIMS analysis.

${ }^{\mathrm{e}}$ Trace elements contents in inclusion glasses determined by SIMS and trace elements contents in matrix glasses determined by LA-ICP-MS. 
${ }^{\mathrm{f}}$ Major elements contents in pre-eruptive $\left(\mathrm{H}_{2} \mathrm{O} \geqslant 5 \mathrm{wt} \%\right.$ in inclusion glasses) and degassing $\left(\mathrm{H}_{2} \mathrm{O}<5 \mathrm{wt} \%\right.$ in inclusion glasses) rhyolitic melts are after Borisova et al. (2005), average $\mathrm{H}_{2} \mathrm{O}$ and trace element contents with standard deviations in the inclusion glasses are according to the SIMS data on Cu, $\mathrm{Zn}$, Mo, $\mathrm{Pb}$ and LREE contents in the melt inclusions, and according to the LA-ICP-MS data on As, $\mathrm{Sb} \mathrm{Cd}$ and Au in the matrix glasses. ${ }^{\mathrm{g}}$ Average major element contents in matrix glasses ( 22 points) with $1 \sigma$ standard deviations determined by EMPA in LMTG; average trace elements contents with $1 \sigma$ standard deviations determined by nanosecond ( $n n, 3$ points for analysis) and femtosecond ( $f m, 6$ points for analysis) LA-ICP-MS. 

A quadrupole-based inductively coupled mass spectrometer (ICP-MS Elan 6000, PerkinElmer SCIEX), nanosecond Laser Ablation System (LSX-200, CETAC) and femtosecond Pulsar IQ Amplitude technologies were used at LMTG, Toulouse, France. The laser ablation system uses an ultraviolet Nd:YAG nanosecond laser operating at a wavelength of $266 \mathrm{~nm}$ in Q-switched mode (Aries et al., 2001) and the femtosecond system operates at a wavelength of $800 \mathrm{~nm}$. The energy level per pulse was $6-12 \mathrm{~mJ}$ and the laser repetition rate was $5-10 \mathrm{~Hz}$. The reference and matrix glasses were analyzed in single-point mode with a pit size diameter of 40-50 $\mu \mathrm{m}$ with the femtosecond laser and 100-140 $\mu \mathrm{m}$ with nanosecond lasers. ${ }^{23} \mathrm{Na},{ }^{42} \mathrm{Ca}$, ${ }^{44} \mathrm{Ca},{ }^{63} \mathrm{Cu},{ }^{65} \mathrm{Cu},{ }^{66} \mathrm{Zn},{ }^{75} \mathrm{As},{ }^{85} \mathrm{Rb},{ }^{88} \mathrm{Sr},{ }^{89} \mathrm{Y},{ }^{90} \mathrm{Zr},{ }^{93} \mathrm{Nb},{ }^{95} \mathrm{Mo},{ }^{114} \mathrm{Cd},{ }^{121} \mathrm{Sb},{ }^{133} \mathrm{Cs},{ }^{138} \mathrm{Ba},{ }^{139} \mathrm{La}$, ${ }^{140} \mathrm{Ce},{ }^{141} \mathrm{Pr},{ }^{172} \mathrm{Yb},{ }^{181} \mathrm{Ta},{ }^{197} \mathrm{Au},{ }^{208} \mathrm{~Pb},{ }^{232} \mathrm{Th}$ and ${ }^{238} \mathrm{U}$ mass peaks were measured with dwell times of 10-20 ms. The acquisition time for one complete analysis was 1.5-2 min. Plasma RF power was 1200-1300 $\mathrm{W}$ and other operating conditions and acquisition parameters of the Perkin-Elmer Elan 6000 ICP-MS were similar to those used by Aries et al. (2001). The data obtained for all silicate glasses have been processed with the GLITTER 4.0 software package. The internal standard was ${ }^{42} \mathrm{Ca}$ because it successfully reproduces the acquired element contents in NIST 610 and 612 standards within $\pm 10 \%$ as compared to the certified values (electronic annex, Table EA1). LA-ICP-MS determined concentrations of $\mathrm{Zn}, \mathrm{Mo}, \mathrm{As}, \mathrm{Sb}, \mathrm{Pb}$, $\mathrm{Rb}, \mathrm{Sr}, \mathrm{U}$ and $\mathrm{Ta}$ in Macusani glass were within $\pm 25 \%$ of the solution-mode values obtained on the bulk-rock Macusani obsidian glass. NIST 610 and 612 were used as the external standards for calibration of LA-ICP-MS analyses. Detection limits for the glass analyses were $14 \mathrm{ppb}$ for $\mathrm{Au}, 0.01-0.3 \mathrm{ppm}$ for Sr, Mo, Sb, REE, Y, Rb, Zr, Nb, Cs, Ba, Pb, Th, U, Ta and 0.3-5 ppm for $\mathrm{Cu}, \mathrm{Zn}$ and $\mathrm{As}, \mathrm{Sb}$ and $\mathrm{Cd}$.

Dust-free chips of the white dacite pumice investigated by Scaillet and Evans, 1999 and Borisova et al., 2005 were cleaned in distilled water, dried and crushed to powder in an agate mortar, previously cleaned with pure quartz sand. To insure complete dissolution of zircon, a fusion-mode dissolution was chosen instead of acid dissolution. About $100 \mathrm{mg}$ of pumice powder were fused together with $600 \mathrm{mg} \mathrm{LiBO}_{2}$ as a flux. Then $100 \mathrm{ml}$ of bi-distilled $10 \%$ $\mathrm{HNO}_{3}$ were added to dissolve the fused glass. After its complete dissolution, a $10 \mathrm{ml}$ aliquot of this solution was furthermore treated so that the final solution $\left(30 \mathrm{ml}, \mathrm{HNO}_{3} 0.37 \mathrm{~N}\right)$ had a dilution factor of 1000 compared to the rock. Indium was used an internal standard. ICP-MS analyses were performed with a Perkin-Elmer Elan 6000 inductively coupled mass spectrometer equipped with a standard cross-flow nebuliser-Scott spray chamber and an automatic sampler. Between every sample the whole system was washed with a $\mathrm{HNO}_{3} 0.37 \mathrm{~N}$ solution to prevent cross-contamination and memory effects. Multi-element standard solutions were run every five samples. REE were analyzed with $\mathrm{RSD}<5 \%$. We used our in-house developed special procedure for oxide and hydroxide interference corrections (Aries et al., 2000) which ensures good accuracy and reproducibility as demonstrated by repeated analyses of the adapted Certified Reference Materials.

\section{Results}

\subsection{Chemistry of the Mt. Pinatubo silicic melts}

\subsubsection{Chemistry of homogenized melt inclusions, matrix glasses and sulfides}

Major and trace element compositions of glasses of 15 homogenized melt inclusions and groundmass are listed in Table 1. The results show excellent agreement with previous EMPA 
analyses (Gerlach et al., 1996 and Borisova et al., 2005). Average $\mathrm{SiO}_{2}\left(78.8 \mathrm{wt} \%\right.$ ) and $\mathrm{Al}_{2} \mathrm{O}_{3}$ $(12.9 \mathrm{wt} \%)$ contents recalculated to the volatile-free basis in inclusion glasses (Table 1) are similar to those previously determined in melt inclusions of the same sample $\left(79.1 \mathrm{wt} \% \mathrm{SiO}_{2}\right.$ and $12.5 \mathrm{wt} \% \quad \mathrm{Al}_{2} \mathrm{O}_{3}$; Borisova et al., 2005). The average $\mathrm{H}_{2} \mathrm{O}$ content $(4.3 \mathrm{wt} \%)$ of homogenized melt inclusions determined by SIMS (Table 1) is similar to that obtained with the same technique for untreated melt inclusions $\left(4.4 \mathrm{wt} \% \mathrm{H}_{2} \mathrm{O}\right.$; Gerlach et al., 1996). It is slightly lower than the average value found in melt inclusions previously determined with the "by-difference" technique in the same sample $\left(5.4 \mathrm{wt} \% \mathrm{H}_{2} \mathrm{O}\right.$; Borisova et al., 2005). However, if the water contents in the $\mathrm{H}_{2} \mathrm{O}$-poor and $\mathrm{H}_{2} \mathrm{O}$-rich inclusions, as defined by Borisova et al. (2005), are averaged separately, the agreement between the SIMS and the "bydifference" data is in fact very good (for example, 1.7 vs. 2.0 and 7.3 vs. $7.2 \mathrm{wt} \%$, for $\mathrm{H}_{2} \mathrm{O}$ poor decrepitated primary melt inclusions and $\mathrm{H}_{2} \mathrm{O}$-rich stable primary melt inclusions), except when the $\mathrm{H}_{2} \mathrm{O}$ contents drops below $1 \mathrm{wt} \%$ (Table 1). The difference between these groups of primary inclusions is their size and the decrepitation character for the largest melt inclusions ( $>80 \mu \mathrm{m}$, Borisova et al., 2005). Major element compositions of groundmass glasses determined by EMPA in this work overlap those previously determined by Gerlach et al. (1996).

Copper and zinc concentrations are characterized by a substantial variability, both in the $\mathrm{H}_{2} \mathrm{O}-$ rich (22-110 ppm Cu; 44-55 ppm $\mathrm{Zn}$ ) and $\mathrm{H}_{2} \mathrm{O}$-poor (31-118 ppm $\mathrm{Cu}$; 30-137 ppm $\mathrm{Zn}$ ) inclusions (Table 1). Other trace elements exhibit less variable concentrations. LREE and Mo concentrations are indistinguishable in $\mathrm{H}_{2} \mathrm{O}$-rich $(15.9 \pm 1.8 \mathrm{ppm} \mathrm{La} ; 16.7 \pm 3.0 \mathrm{ppm} \mathrm{Ce}$; $1.4 \pm 0.3 \mathrm{ppm} \mathrm{Pr} ; 1.9 \pm 0.14 \mathrm{ppm} \mathrm{Mo})$ and $\mathrm{H}_{2} \mathrm{O}$-poor (18.8 $\pm 1.7 \mathrm{ppm} \mathrm{La} ; 21.2 \pm 2.7 \mathrm{ppm} \mathrm{Ce}$; $1.9 \pm 0.3 \mathrm{ppm}$ Pr; $2.1 \pm 0.05 \mathrm{ppm}$ Mo) inclusions within the precision of SIMS analysis. Therefore, the available data show that the trace element contents of the $\mathrm{H}_{2} \mathrm{O}$-rich and $\mathrm{H}_{2} \mathrm{O}$ poor melt inclusions overlap. Lead concentrations could be determined in the $\mathrm{H}_{2} \mathrm{O}$-poor inclusions only $\left(15.7 \pm 2.4 \mathrm{ppm} \mathrm{Pb}\right.$, Table 1). Except for volatile $\mathrm{H}_{2} \mathrm{O}$ the decrepitation process at 13-24 MPa should not change the major and trace element contents of the primary melt inclusions (e.g., Borisova et al., 2005). Average values of matrix glass LREE, Mo and $\mathrm{Pb}$ concentrations by LA-ICP-MS $(15 \pm 0.7 \mathrm{ppm} \mathrm{La;} 28 \pm 1.1 \mathrm{ppm} \mathrm{Ce} ; 2.3 \pm 0.12 \mathrm{ppm} \mathrm{Pr}$; $1.5 \pm 0.3 \mathrm{ppm} \mathrm{Mo} ; 16 \pm 0.6 \mathrm{ppm} \mathrm{Pb}$ ) are similar to melt inclusion SIMS values (Table 1). $\mathrm{Cu}$ and $\mathrm{Zn}$ contents in the matrix glass $(35.6 \pm 4 \mathrm{ppm} \mathrm{Cu} ; 113 \pm 20 \mathrm{ppm} \mathrm{Zn})$ are also similar to those of the inclusion averages $(71 \pm 36 \mathrm{ppm} \mathrm{Cu}$ and $73 \pm 35 \mathrm{ppm} \mathrm{Zn})$. The matrix glass analyses yield average As and $\mathrm{Sb}$ contents of $18.7 \pm 3.5$ and $1.4 \pm 0.35 \mathrm{ppm}$, respectively; and one analysis of matrix glass yields $22 \pm 8 \mathrm{ppb}$ of $\mathrm{Au}$. Based on the data on LREE, Mo and $\mathrm{Pb}$ we conclude that the matrix glass has trace element concentrations very close to the inclusions taken as a whole (Table 1). This indicates that syn-eruptive degassing (Borisova et al., 2005) has little influence on the trace element chemistry of the analyzed silicate glasses. Major and trace element compositions of chalcopyrite with high concentrations of $\mathrm{Fe}, \mathrm{Cu}$ and $\mathrm{Zn} \mathrm{(30.0-}$ 30.4 at $\% \mathrm{Fe}, 26-28$ at $\% \mathrm{Cu}$ and $0.67-0.76$ at $\% \mathrm{Zn}$, respectively, Table 2) are close to those previously published by Hattori (1993). 
Table 2. : Major and trace element compositions of the Mt. Pinatubo parental dacitic and the pre-eruptive rhyolitic melts and the estimated compositions of equilibrium aqueous fluids according to the available experimental partition coefficients

\begin{tabular}{|c|c|c|c|c|c|c|}
\hline & $\begin{array}{l}\text { Parental dacitic } \\
\text { melt }^{\mathbf{a}}\end{array}$ & $\begin{array}{l}\text { Fluid of dacitic } \\
\text { melt }^{\underline{b}}\end{array}$ & $\begin{array}{l}\text { Pre-eruptive rhyolitic } \\
\text { melt }^{\mathrm{c}}\end{array}$ & $\begin{array}{l}\text { Pre-eruptive aqueous } \\
\text { fluid }^{\underline{d}}\end{array}$ & $\begin{array}{l}\text { Sulfide } \\
\text { phases }^{\text {e }}\end{array}$ & $K_{d}$ fluid$/$ melt $^{\mathbf{f}}$ \\
\hline & wt\%/ppm/ppb & $\begin{array}{l}\text { Calculated } \\
\text { wt\%/ppm }\end{array}$ & wt\%/ppm/ppb & Calculated wt\%/ppm & ppm & Experimental \\
\hline $\mathrm{SiO}_{2}(\mathrm{wt} \%)$ & 65.17 & - & 79.7 & - & - & - \\
\hline $\mathrm{TiO}_{2}$ & 0.52 & - & 0.09 & - & - & - \\
\hline $\mathrm{Al}_{2} \mathrm{O}_{3}$ & 16.34 & - & 12.0 & - & - & - \\
\hline $\mathrm{FeO}^{\mathrm{c}}$ & 4.16 & - & 0.60 & - & 47.26 & - \\
\hline $\mathrm{MgO}$ & 2.44 & 0.50 & 0.15 & - & - & $0.033 \times[C l]^{2}$ \\
\hline $\mathrm{CaO}$ & 5.22 & 2.62 & 1.03 & - & - & $0.0804 \times[C l]^{2}$ \\
\hline $\mathrm{Na}_{2} \mathrm{O}$ & 4.65 & 5.44 & 3.4 & 6.37 & - & $0.468 \times[C l]$ \\
\hline $\mathrm{K}_{2} \mathrm{O}$ & 1.56 & - & 2.9 & - & - & - \\
\hline $\mathrm{H}_{2} \mathrm{O}(\mathrm{wt} \%)$ & 10 & - & 7.3 & - & - & - \\
\hline $\mathrm{Cl}$ ppm & $474 \pm 33$ & 87672 & 1033 & 37935 & - & 185 \\
\hline $\mathrm{HCl}(\mathrm{ppm})$ & $487 \pm 35$ & 90164 & 1062 & 39013 & - & - \\
\hline $\mathrm{Cl}\left(\mathrm{mol} / \mathrm{kg}^{\text {fluid }}\right)$ & - & 2.47 & - & 1.07 & - & - \\
\hline $\mathrm{S}(\mathrm{ppm})$ & $1361 \pm 588$ & - & 74 & - & 357,261 & - \\
\hline $\mathrm{Sr}(\mathrm{ppm})$ & 556.7 & 383 & 167.6 & 22 & - & $0.11 \times[C l]^{2}$ \\
\hline $\mathrm{Y}$ & 12.4 & - & 3.5 & - & - & - \\
\hline
\end{tabular}




\begin{tabular}{|c|c|c|c|c|c|c|}
\hline & $\begin{array}{l}\text { Parental dacitic } \\
\text { melt }^{\underline{a}}\end{array}$ & $\begin{array}{l}\text { Fluid of dacitic } \\
\text { melt }^{\underline{b}}\end{array}$ & $\begin{array}{l}\text { Pre-eruptive rhyolitic } \\
\text { melt }^{\underline{ }}\end{array}$ & $\begin{array}{l}\text { Pre-eruptive aqueous } \\
\text { fluid }{ }^{\mathrm{d}}\end{array}$ & $\begin{array}{l}\text { Sulfide } \\
\text { phases }^{-}\end{array}$ & $K_{\text {d }}$ fluid/melt ${ }^{\underline{f}}$ \\
\hline & wt\%/ppm/ppb & $\begin{array}{l}\text { Calculated } \\
\text { wt\%/ppm }\end{array}$ & wt\%/ppm/ppb & Calculated wt\%/ppm & ppm & Experimental \\
\hline $\mathrm{La}$ & $15.59 \pm 0.37$ & - & $15.9 \pm 1.8$ & - & - & - \\
\hline $\mathrm{Ce}$ & $32.40 \pm 1.17$ & - & $16.7 \pm 3.0$ & - & - & - \\
\hline $\operatorname{Pr}$ & 3.66 & - & $1.4 \pm 0.3$ & - & - & - \\
\hline $\mathrm{Zn}$ & $52.9 \pm 2.6$ & 3108 & $49 \pm 5$ & 830 & 4,667 & $9.4 \times[C l]^{2}$ \\
\hline $\mathrm{Cu}$ & $25.5 \pm 13.8$ & 1274 & $77 \pm 48$ & 770 & 264,873 & $9.1 \times[C l]$ \\
\hline Mo & 0.908 & 2 & $1.9 \pm 0.14$ & 5 & - & 2.5 \\
\hline $\mathrm{Pb}$ & $9.93 \pm 1.75$ & 140 & $15.7 \pm 2.4$ & 44 & 1,379 & $2.26 \times[C l]^{2}$ \\
\hline As & $3.42 \pm 0.25$ & - & $18 \pm 3.5$ & - & 308 & - \\
\hline $\mathrm{Sb}(\mathrm{ppm})$ & $0.33 \pm 0.12$ & - & $1.4 \pm 0.35$ & - & - & - \\
\hline $\mathrm{Au}(\mathrm{ppb})$ & 6.4 & $0.25 ;[38]$ & $22 \pm 8$ & $0.38 ;[130]$ & - & $\begin{array}{l}\exp (2.2 \times \log [\mathrm{HCl}]-7.2) \\
{[5900]}\end{array}$ \\
\hline $\begin{array}{l}\text { Magmatic } \quad \text { phases } \\
\text { fractions }(w t \%)\end{array}$ & 100 & - & $42.8-44.7$ & - & $0.05-2.0$ & - \\
\hline
\end{tabular}

${ }^{\text {a }}$ Parental dacitic melt composition is average bulk rock analyses of the Mt. Pinatubo white dacite pumice obtained in this work for Mo, Pr and Au and published data (with $1 \sigma$ standard deviations) from Bernard et al., 1996, Fournelle et al., 1996, Luhr and Melson, 1996 and Pallister et al., 1996; Variable S contents in white dacite pumices are explained by secondary alteration of magmatic anhydrite (e.g., Bernard et al., 1996). Variable Cu could be due to desulfidization process; Au in ppb.

${ }^{b}$ Composition of aqueous fluid in equilibrium with dacitic melt is calculated according to fluid/melt partitioning of Webster (1992a) for $\mathrm{Cl}$, $\mathrm{Cl}$ mol/kg or $\mathrm{HCl}$ ppm contents of the fluid and metal fluid/melt partitioning. ${ }^{\mathrm{f}}$

${ }^{c}$ The Mt. Pinatubo pre-eruptive rhyolitic melt composition is average major and trace element composition for melt inclusions homogenized at $760{ }^{\circ} \mathrm{C}$ and $200 \mathrm{MPa}$ (major elements, $\mathrm{Cu}, \mathrm{Zn}, \mathrm{Pb}, \mathrm{Mo}, \mathrm{La}, \mathrm{Ce}$ and Pr, Table 1) and matrix glasses (Sr, Y, As, Sb and Au measured by LA-ICP-MS, Table 1) with standard deviations; S and Cl contents are from Borisova et al. (2005); Au in ppb; The fractions of rhyolitic glass in dacite is after Luhr and Melson, 1996 and Bernard et al., 1996.

${ }^{\mathrm{d}}$ Composition of fluid in equilibrium with rhyolitic melt is determined based on fluid/melt partitioning of Webster $(1992 \mathrm{~b})$ for $\mathrm{Cl}$, [Cl] mol/kg or $\mathrm{HCl}$ ppm contents of the 
fluid and metal fluid/melt partitioning. ${ }^{\mathrm{f}}$

${ }^{\mathrm{e}}$ Sulfide phase composition is chalcopyrite analyzed by EMPA in this work. The estimate of $0.05-2.0 \mathrm{wt} \%$ fraction of sulfides in dacite pumices is made using the data on Cu and $\mathrm{Zn}$ concentrations in rhyolitic melt, sulfide and the host dacite magma and the fraction of rhyolitic melt in the magma.

${ }_{\mathrm{f}}^{\mathrm{f}}$ Metal fluid/melt partitioning of Urabe (1985) for Na, Pb and Zn; Carron and LaGache (1980) for Sr; Holland (1972) for Mg and Ca; Candela and Holland (1984) for Mo and

$\mathrm{Cu}$ based on $\mathrm{Cu}$ content 56 ppm of Pallister et al., 1996, Frank et al., 2002 and Hanley et al., 2005 for Au (in ppm), [Cl] (in mol/kg) and HCl (in ppm). 


\subsubsection{Chemistry of the bulk-rock white dacite pumices}

Average major and trace element data for the bulk dacite pumices are listed in Table 2 and enrichment/depletion patterns relative to N-MORB are illustrated in Fig. 3. The new ICP-MS data for white dacite pumice yield $28.3 \mathrm{ppm} \mathrm{Cu}, 11.3 \mathrm{ppm} \mathrm{Pb}, 4.3 \mathrm{ppm}$ As, $0.8 \mathrm{ppm} \mathrm{Sb}$, $13.0 \mathrm{ppm} \mathrm{La}, 30.6 \mathrm{ppm} \mathrm{Ce}, 577.1 \mathrm{ppm} \mathrm{Sr}$ and $13.6 \mathrm{ppm} \mathrm{Y}$. These values are in close agreement with literature data (Table 2). The Au (6.4 ppb), Mo (0.91 ppm) and Pr (3.7 ppm) concentration data are reported for the first time for the Pinatubo dacite (Table 2).

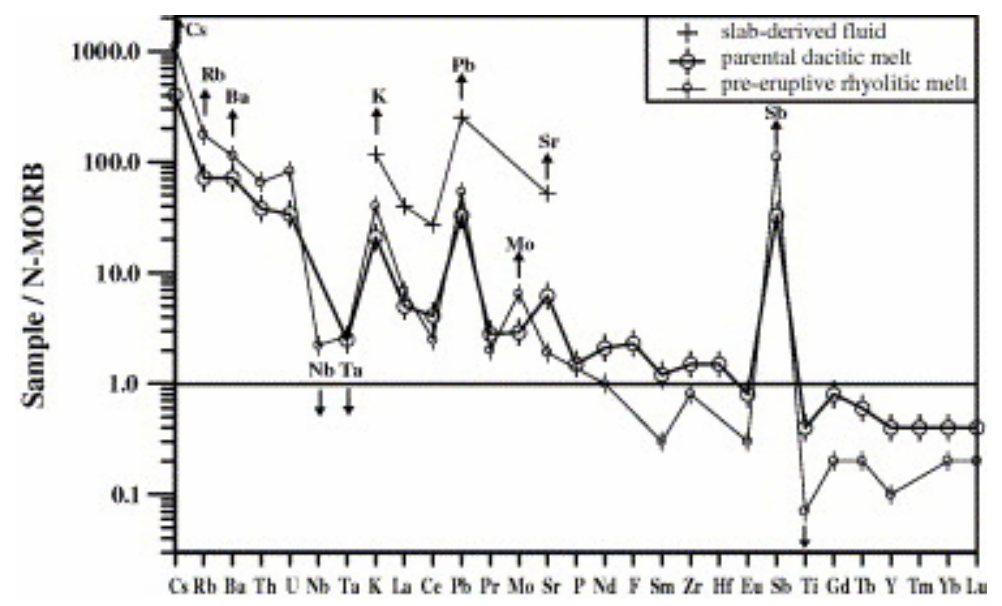

Fig. 3. N-MORB-normalized pattern of the parental dacitic melt and the pre-eruptive rhyolitic melt. Data on the composition of the dacitic melt are those of the white dacite pumices (Bernard et al., 1996, Fournelle et al., 1996, Luhr and Melson, 1996 and Pallister et al., 1996), original data for Au, Mo and Pr, (Table 2). The pre-eruptive melt composition is according to original data (Table 1 and Table 2). Enrichment in $\mathrm{Cs}, \mathrm{Rb}, \mathrm{Ba}, \mathrm{Th}, \mathrm{U}, \mathrm{K}, \mathrm{Pb}, \mathrm{Sr}$, Mo and Sb relative to "adjacent" REE and depletion in $\mathrm{Ta}, \mathrm{Nb}$ and Ti relative to "adjacent" REE are highlighted by arrows. Normalization to N-MORB composition of Sun and McDonough (1989) is applied. ICP-MS analysis of white dacite pumice in this work yields the following trace element contents: $0.908 \mathrm{ppm} \mathrm{Mo,} 11.3 \mathrm{ppm} \mathrm{Pb}$, 13 ppm La, 30.6 ppm Ce, 577 ppm Sr, and 13.6 ppm Y (and Table 2). LA-ICP-MS analysis of rhyolitic glasses of groundmass yields the following trace element contents: $98.57 \pm 4.31 \mathrm{ppm} \mathrm{Rb}, 7.66 \pm 0.4 \mathrm{ppm} \mathrm{Cs}$, $719 \pm 63 \mathrm{ppm} \mathrm{Ba}, 0.36 \pm 0.04 \mathrm{ppm}$ Ta, $5.14 \pm 0.28 \mathrm{ppm} \mathrm{Nb}, 7.93 \pm 0.35 \mathrm{ppm}$ Th, $3.88 \pm 0.23 \mathrm{ppm} \mathrm{U}$,

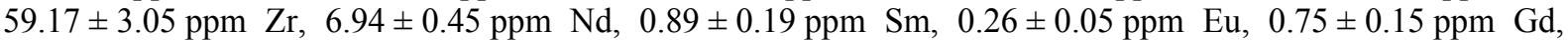
$0.1 \pm 0.02 \mathrm{ppm} \mathrm{Tb}, 0.48 \pm 0.09 \mathrm{ppm} \mathrm{Yb}, 0.1 \pm 0.02 \mathrm{ppm}$ Lu (and Table 1 and Table 2).

Differences in major element contents between the bulk rock dacite and rhyolitic glasses of the matrix and inclusions are represented by $\mathrm{Ti}, \mathrm{Al}, \mathrm{Fe}, \mathrm{Mg}, \mathrm{Ca}$ and $\mathrm{Na}$ enrichment in the dacite, and $\mathrm{Si}, \mathrm{K}$ enrichment in the rhyolitic glasses. In addition, Sr, Y and REE (except for $\mathrm{La}$ ) are enriched, and $\mathrm{Cs}, \mathrm{Rb}$ and $\mathrm{Ba}$ are depleted in the dacite relative to the inclusion and matrix glasses (Fig. 3). Au (6.4 vs. 22 ppb), Cu (28 vs. 71 ppm), Pb (10 vs. 16 ppm), Mo (0.9 vs. $2.0 \mathrm{ppm})$, As (3.4 vs. $11 \mathrm{ppm})$, and $\mathrm{Sb}(0.3$ vs. $1.1 \mathrm{ppm})$ are enriched in the rhyolitic glasses relative to the bulk dacite. For $\mathrm{Zn}$, the concentrations are similar. 


\section{Discussion}

\subsection{Adakite magma differentiation and metal concentration}

\subsubsection{Significance of the Mt. Pinatubo dacite and related rhyolitic glasses}

Mt. Pinatubo is one of numerous active volcanoes in the West Central Luzon volcanic chain which are associated with eastward subduction of the Eurasian plate along the Manila trench (Fig. 1). The high $\mathrm{Al}_{2} \mathrm{O}_{3}$ (15-17 wt\%), high $\mathrm{Sr}$ (474-608 ppm) and low Y (11-14 ppm) contents (Table 2), very low $\mathrm{Rb} / \mathrm{Sr}(0.06-0.10)$ and $\mathrm{K} / \mathrm{Rb}$ (264-338) ratios together with high LREE enrichment and a lack of any $\mathrm{Eu}$ anomaly in the Mt. Pinatubo dacites are typical features of the high-Al adakites (Drummond and Defant, 1990 and Bernard et al., 1996). Recent experimental data indicate that the most plausible mechanism for the genesis of the Mt. Pinatubo dacite magma is high-pressure fractionation of hydrous, oxidizing, primitive basalt that crystallized amphibole and garnet upon cooling (Prouteau and Scaillet, 2003). The steep negative slopes of the N-MORB-normalized patterns (Fig. 3) are consistent with the fractionation of amphibole and garnet phases. The Ta, Nb and Ti depletion in the N-MORBnormalized patterns (Fig. 3) also confirms the presence of hornblende and/or magnetite during high-pressure crystallisation.

The experimental work of Rutherford and Devine, 1996 and Scaillet and Evans, 1999 at $220 \mathrm{MPa}$ (which is in the range of $190 \pm 50 \mathrm{MPa}$, the total pressure of dacite magma crystallization just prior to eruption, Borisova et al., 2005) has essentially reproduced both the phase assemblage and composition of the Mt. Pinatubo dacites, with the exception of the rare high-Al hornblende cores and calcic plagioclase which together represent $<1 \%$ of the phenocryst volume (Prouteau and Scaillet, 2003). These data imply that the dacite magma arrived in a nearly molten state in the pre-eruptive reservoir where major crystallization occurred (e.g., Prouteau et al., 1999 and Prouteau and Scaillet, 2003). We suggest, therefore, that the bulk composition of the dacite pumice closely reflects the chemistry of the parental dacitic melt. In the same way, the composition of rhyolitic melt inclusions and matrix glass reflects the chemistry of the residual melt which results from crystallization of the dacite at its pre-eruptive storage level. These parental-residual relationships offer the opportunity to discuss the behaviour of metals during differentiation of adakitic magma.

\subsubsection{Metal concentrations}

The concentrations of ore metals in the residual rhyolitic melt $(\mathrm{Au}=22 \pm 8 \mathrm{ppb}$, and average $\mathrm{Cu}=71 \pm 36 \mathrm{ppm}, \quad \mathrm{Pb}=16 \pm 2 \mathrm{ppm}, \quad \mathrm{Mo}=2.0 \pm 0.1 \mathrm{ppm}, \quad$ As $=11 \pm 1.9 \mathrm{ppm}$, $\mathrm{Sb}=1.1 \pm 0.2 \mathrm{ppm}$ ) are by a factor of $2-3$ higher than those in the parental dacitic melt (Au $\sim$ $6.4 \mathrm{ppb}, \mathrm{Cu} \approx 28 \mathrm{ppm}, \mathrm{Pb}=10 \pm 1.8 \mathrm{ppm}, \mathrm{Mo} \approx 0.9 \mathrm{ppm}, \quad \mathrm{As} \approx 3.4 \mathrm{ppm}$ and $\mathrm{Sb} \sim$ $0.33 \mathrm{ppm})$. Note however that the $\mathrm{Zn}$ concentration in the pre-eruptive rhyolitic melt $(73 \pm 35 \mathrm{ppm})$ is not distinguishable within error from that of the parental dacitic melt $(53 \pm 3 \mathrm{ppm})$. Overall, these data reflect the incompatible behaviour of ore metals during dacite magma crystallization and differentiation (Fig. 4). The increase in $\mathrm{Au}, \mathrm{Cu}, \mathrm{Pb}, \mathrm{Mo}, \mathrm{As}$ and $\mathrm{Sb}$ in silicic melts is accompanied by an increase in chlorine content (474-1033 ppm) and a dramatic decrease in sulphur contents (1361-74 ppm) during crystallization of the dacite magma (Fig. 4). 


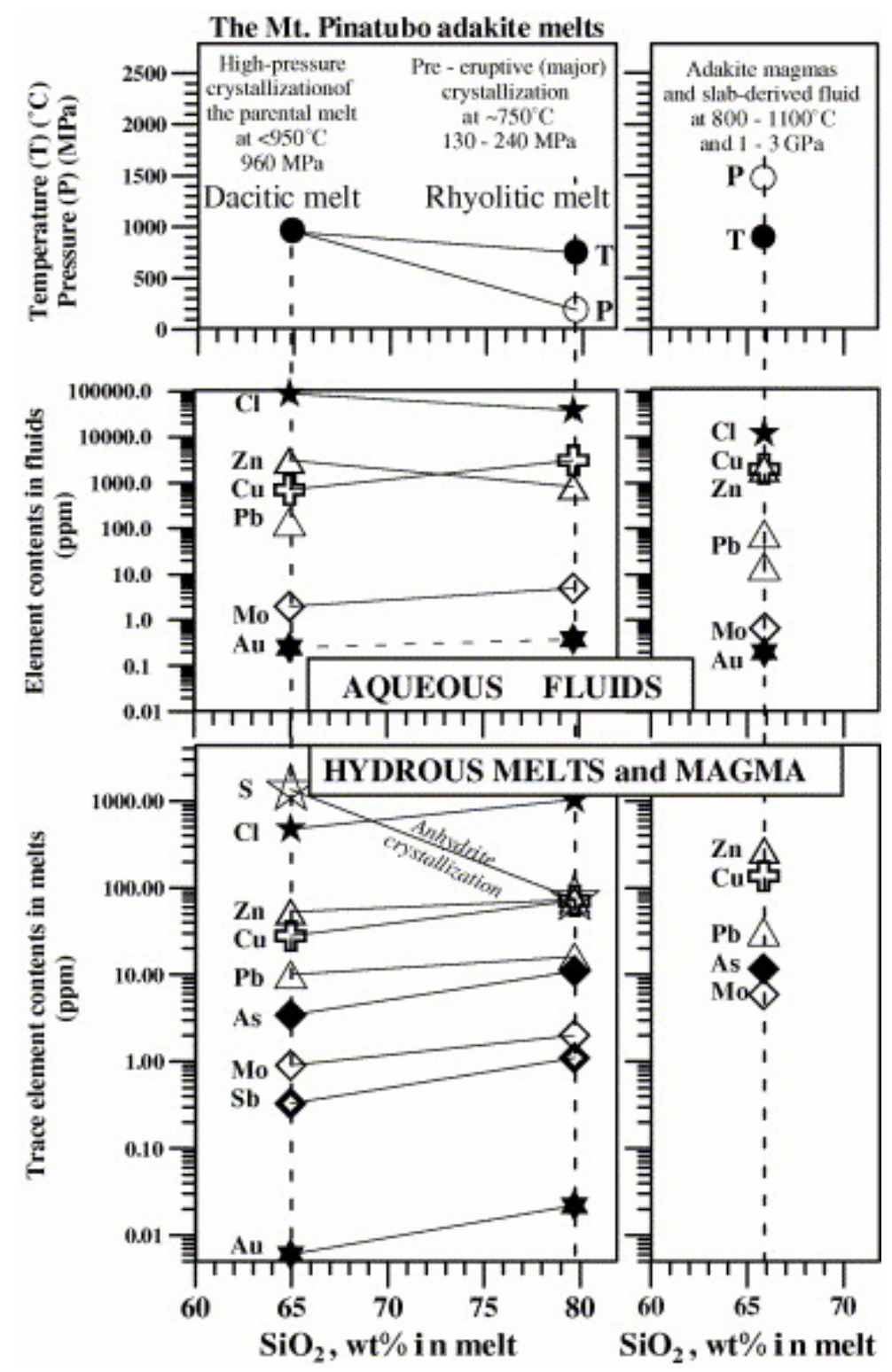

Fig. 4. Chemistry of hydrous melts and equilibrium aqueous fluids. Temperature $\left({ }^{\circ} \mathrm{C}\right)$-pressure (MPa) conditions of the Mount Pinatubo magma crystallization, together with trace element compositions in co-existing melts and fluids versus $\mathrm{SiO}_{2}$ contents in melts. The high-pressure crystallization stage of the parental dacitic melt at $950{ }^{\circ} \mathrm{C}, 960 \mathrm{MPa}$ and the pre-eruptive crystallization of the rhyolitic melt at $750{ }^{\circ} \mathrm{C}$ and total pressure of $190 \pm 50 \mathrm{MPa}$ are shown. Adakite magma and slab-derived fluid at $800-1100{ }^{\circ} \mathrm{C}$ and $1-3 \mathrm{GPa}$ are illustrated. Trace element data of the melts and fluids are from Table 2 and Table 3.

Highly oxidizing conditions during magma differentiation are favorable for concentrating ore metals in the residual melt, because high oxygen fugacity eliminate the early segregation of sulfides (e.g., pyrrhotite) which may act as a sink for $\mathrm{Cu}, \mathrm{Zn}$ and $\mathrm{Au}$ (e.g., Candela, 1989). At least two phases controlled the ore metals chemistry of the dacite magma at the pre-eruptive conditions, chalcopyrite ( $\leqslant 2 \mathrm{wt} \%$ ) with high concentrations of $\mathrm{Cu}, \mathrm{Zn}$ and rhyolitic melt (43$45 \mathrm{wt} \%$ ) which forms the groundmass (Table 2). Chalcopyrite globules occur as multiphase inclusions in dacite phenocrysts (Fig. 2) and resorbed chalcopyrite segregations are found in the rhyolitic glass matrix (Table 2). The magma differentiation occurred at oxidizing conditions, above $\mathrm{NNO}+1$, at conditions where sulfate species $\left[\mathrm{SO}_{4}\right]$ dominate over sulfide complexes $[\mathrm{S}]^{2-}$ in the hydrous melts (Fig. 5). This significantly reduces sulfide phase 
formation and fractionation. A limited amount of titanomagnetite $(<4 \mathrm{wt} \%)$, crystallized under the Mt. Pinatubo high-pressure conditions (Prouteau and Scaillet, 2003), which may explain why the dacite magma was finally enriched in Zn and Mo (Fig. 3).

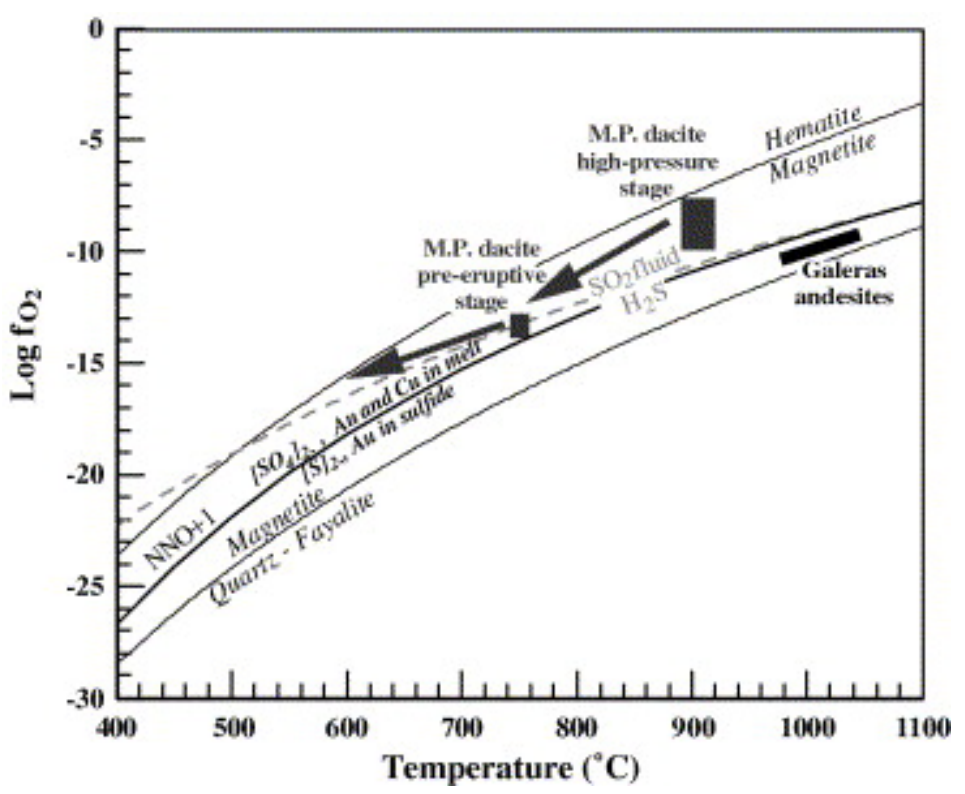

Fig. 5. $\log f_{\mathrm{O} 2}$ versus temperature $\left({ }^{\circ} \mathrm{C}\right)$ showing redox conditions for the Mt. Pinatubo crystallization stages. The high-pressure redox conditions are according to Prouteau and Scaillet (2003) and the pre-eruptive redox conditions are from Borisova et al., 2005 and Scaillet and Evans, 1999. $T-f_{\mathrm{O} 2}$ conditions for the Galeras andesites related to $\mathrm{Au} / \mathrm{Cu}$ deposits are from Goff et al. (1994). Thin solid curves, hematite-magnetite and magnetite-quartz-fayalite equilibria; thick solid curve, $f_{\mathrm{O} 2}$ corresponding to $\mathrm{NNO}+1$. This curve also delimits the predominance of sulfate $\left[\mathrm{SO}_{4}\right]^{2-}$ versus sulfide $[\mathrm{S}]^{2-}$ in the hydrous silicic melts (Carroll and Rutherford, 1987, Andersen and Lindsley, 1988 and Clemente et al., 2004). Au, Cu in melt versus Au in sulfide boundary are according to Mungall (2002) and corresponding to NNO + 1. Dashed curve corresponds to a $1: 1 \mathrm{SO}_{2}$ and $\mathrm{H}_{2} \mathrm{~S}$ ratio in the fluid, according to the reaction $\mathrm{H}_{2} \mathrm{~S}+1.5 \mathrm{O}_{2}=\mathrm{SO}_{2}+\mathrm{H}_{2} \mathrm{O}$ (Carroll and Rutherford, 1987).

\subsubsection{Constraints on the chemistry of aqueous fluids}

Although an aqueous fluid phase was trapped in rare inclusions in quartz (Pasteris et al., 1996), most fluid inclusions were decrepitated and the fluid was not retained (Fig. 2). The chemistry of the primary fluid (e.g., $\mathrm{SO}_{2}, \mathrm{H}_{2} \mathrm{~S}, \mathrm{HCl}$, trace element contents) should depend on the chemistry of the associated hydrous melts and pressure-temperature and redox conditions $\left(P-T-f_{\mathrm{O} 2}\right)$. The high $\mathrm{Cl}$ concentrations, above $500-1000 \mathrm{ppm}$, in the silicic melts imply these melts were close to saturation with chlorine (Metrich and Rutherford, 1992). The experimentally established empirical correlations between $\mathrm{Cl} \mathrm{mol} \%$ or $\mathrm{HCl} \mathrm{wt} \%$ contents and trace element concentrations in magmatic fluids (e.g., Candela and Holland, 1984, Urabe, 1985 and Frank et al., 2002) put reliable constraints on $\mathrm{Cl}$ content in the fluid. We used data on $\mathrm{Cl}$ contents in melts (Table 2) and available experimental data on $\mathrm{Cl}$ partitioning at 800 $1000^{\circ} \mathrm{C}$ and 200-800 MPa for silicic melts (Table 2; Metrich and Rutherford, 1992, Webster, 1992a and Webster, 1992b). The parental dacitic melt and the pre-eruptive rhyolitic melt are highly peraluminous with $\mathrm{A} / \mathrm{NK}=\mathrm{Al} /(\mathrm{Na}+\mathrm{K})$ of $1.5-1.8$ and $\mathrm{N} / \mathrm{NK}=\mathrm{Na} /(\mathrm{Na}+\mathrm{K})$ of $0.6-$ $0.7 \mathrm{~mol} \%$. Unfortunately, no experimental data exist on the $\mathrm{Cl}$ partitioning for such melts. We assume $\mathrm{Cl}$ partitioning for the parental dacitic melt to be similar to that of subaluminous melts with lower $\mathrm{A} / \mathrm{NK}(1.02-1.04)$ and similar $\mathrm{N} / \mathrm{NK}(0.67-0.68)$ at $800{ }^{\circ} \mathrm{C} / 800 \mathrm{MPa}$ and $\mathrm{Cl}_{\text {melt }}$ contents of $300-700 \mathrm{ppm}$ (Webster, 1992a) and $\mathrm{D}_{\mathrm{Cl}}\left(\mathrm{D}_{\mathrm{Cl}}=\right.$ concentration of $\mathrm{Cl}$ in 
fluid/concentration of $\mathrm{Cl}$ in melt) to be equal to 185 (Table 2). These data yield $2.5 \mathrm{~mol} / \mathrm{kg}$ of chloride in the fluid in equilibrium with the parental dacitic melt at $800{ }^{\circ} \mathrm{C}$ and $800 \mathrm{MPa}$. Similarly, we expect $\mathrm{Cl}$ concentrations in the pre-eruptive fluid in equilibrium with the residual rhyolite melt to be similar to those of peraluminous melts with lower $\mathrm{A} / \mathrm{NK}$ (1.2) and similar N/NK (0.7) (at $800{ }^{\circ} \mathrm{C} / 210 \mathrm{MPa}$ and $\mathrm{Cl}_{\text {melt }}$ contents $1180 \mathrm{ppm}$; Webster, 1992b) and to be equal to $\sim 1.1 \mathrm{~mol} / \mathrm{kg}$. Thermodynamic calculations indicate that $\mathrm{SO}_{2} / \mathrm{H}_{2} \mathrm{~S} / \mathrm{HCl}$ species existed in comparable amounts in the Mt. Pinatubo pre-eruptive fluid (e.g., Gerlach et al., 1996 and Scaillet et al., 1998). The soft chalcophile metals ( $\mathrm{Au}, \mathrm{Cu}$ ) form much more stable complexes with soft ligands like $\mathrm{HS}^{-}$than with moderately hard $\mathrm{Cl}^{-}$and $\mathrm{OH}^{-} / \mathrm{H}_{2} \mathrm{O}$ in aqueous fluids (e.g., Pokrovski et al., 2005). However, the abundant anhydrite crystallization in melt and fluid (e.g., Pasteris et al., 1996) should result in a decrease of the fluid-phase sulfur contents, causing $\mathrm{Cu}, \mathrm{Au}, \mathrm{Pb}$ and $\mathrm{Zn}$ complexation with the far more abundant $\mathrm{Cl}^{-}$in the preeruptive fluid, whereas $\mathrm{As}, \mathrm{Sb}$ and Mo are expected to form soluble hydroxide complexes (e.g., Wood and Samson, 1998, Pokrovski et al., 2005 and Pokrovski et al., 2002).

High- $\mathrm{Al}$ adakitic magmas related to $\mathrm{Au} / \mathrm{Cu}$ and $\mathrm{Cu} / \mathrm{Mo}$ mineralization are peraluminous (González-Partida et al., 2003, Reich et al., 2003, Qu et al., 2004 and Whalen et al., 2004). Most of these magmas contain early phenocrysts of hydrous minerals such as hornblende and biotite, implying early magma saturation with an aqueous fluid (Sajona and Maury, 1998). The peraluminous compositions of the hydrous dacitic and rhyolitic melts saturated with an aqueous fluid suggest partitioning for $\mathrm{Au}, \mathrm{Cu}, \mathrm{Zn}, \mathrm{Pb}$ and $\mathrm{Mo}$ in favor of the fluid phase (Candela and Holland, 1984, Urabe, 1985, Hoosain and Baker, 1996 and Hanley et al., 2005). To estimate $\mathrm{Au}, \mathrm{Cu}, \mathrm{Zn}, \mathrm{Pb}, \mathrm{Mo}$ and $\mathrm{Na}$ contents in aqueous fluids in equilibrium with the Mt. Pinatubo pre-eruptive rhyolitic and the parental dacitic melts, we used the available experimental partitioning coefficients for synthetic melts at $750-800{ }^{\circ} \mathrm{C} / 140-200 \mathrm{MPa}$ for the pre-eruptive rhyolitic melt, and at $800-1250{ }^{\circ} \mathrm{C} / 350-900 \mathrm{MPa}$ for high-pressure dacitic melt (Fig. 4, Table 2). Our estimations show that the Mt. Pinatubo aqueous fluids could contain $0.3-0.4 \mathrm{ppm}$ of $\mathrm{Au}, 770-1300 \mathrm{ppm}$ of $\mathrm{Cu}, 830-3100 \mathrm{ppm}$ of $\mathrm{Zn}$ and $44-140 \mathrm{ppm}$ of $\mathrm{Pb}, 2-$ $5 \mathrm{ppm}$ of $\mathrm{Mo}$, and $6-11 \mathrm{wt} \%$ of $\mathrm{NaCl}$ (Table 2). Higher Au fluid contents (37-130 ppm) could be obtained using partitioning coefficients of Hanley et al. (2005) for a peraluminous system. Because at least 100-500 Mt of $\mathrm{H}_{2} \mathrm{O}$ was liberated from the pre-eruptive magma as aqueous fluid (Gerlach et al., 1996), the calculated fluid composition suggests that the pre-eruptive fluid might have extracted a minimum of $15 \times 10^{5} \mathrm{t}$ of $\mathrm{Cu}$ and $100 \mathrm{t}$ of $\mathrm{Au}$ from the differentiated dacite magma. Provided that metal transport and precipitation mechanisms are efficient, the estimated $\mathrm{Au}$ and $\mathrm{Cu}$ amounts are sufficient to form a typical porphyry-type deposit and thus demonstrate that the degassing adakitic magma is likely to be the primary source for ore metals in porphyry-epithermal environments of subduction zones.

\subsection{Role of slab-derived fluid in defining the geochemistry of the Mt. Pinatubo adakite melts}

The very high sulfur content of the Mt. Pinatubo dacite pumices (reaching up to $2200 \mathrm{ppm}$, Bernard et al., 1991), high Se and Se/S ratio in primary sulfides of the dacites (Hattori, 1993 and Hattori, 1996) indicate that a component enriched in S and Se was involved in the genesis of the dacite. High Se/S ratios are observed in marine sediments (Goldschmidt, 1954) and the involvement of subducted sediments in the genesis of the Mt. Pinatubo dacite is also confirmed by Be isotope signatures (Bernard et al., 1996). Moreover, high $\mathrm{Cl}$ contents in the bulk dacitic and rhyolitic melts (Table 2), and in apatite inclusions (Borisova et al., 2005) strongly support an involvement of subducted components (sediments or metabasalts altered with seawater, Ito et al., 1983) in the genesis of the Mt. Pinatubo dacitic magma. Water 
contents of the Mt. Pinatubo primary melts could be as high as $10-15 \mathrm{wt} \%$, provided the melt saturation with an aqueous fluid occurs at high-pressure conditions (Fig. 4); such high $\mathrm{H}_{2} \mathrm{O}$ contents imply water derivation from the dehydrated oceanic slab.

The high $\mathrm{Au}$ contents $(6.4 \mathrm{ppb})$ of the Mt. Pinatubo dacitic pumices relative to regular calcalkaline magmas (maximum of 2-3 ppb Au; Connors et al., 1993 and Polvé et al., 2004), along with the existence of strong positive anomalies of $\mathrm{Sb}, \mathrm{Pb}$ and Mo relative to "adjacent" REE in the N-MORB-normalized patterns of the bulk dacite pumices and rhyolitic melt (Fig. 3), clearly demonstrate an enrichment of the Mt. Pinatubo adakitic magma in these ore metals. Sulfide melt or mineral phases are the main sink for trace chalcophile metals like $\mathrm{Au}, \mathrm{Cu}, \mathrm{Zn}$ and $\mathrm{Pb}$. However, high $\mathrm{Au}$ and associated metals contents in dacite pumices and rhyolitic melts (Table 2) suggest that sulfide phases must be absent from their sources, and possible interactions with the overlying mantle wedge should be limited (e.g., Mungall, 2002). The high $\mathrm{Pb} / \mathrm{Ce}, \mathrm{Mo} / \mathrm{Ce}, \mathrm{As} / \mathrm{Ce}$ and $\mathrm{Sb} / \mathrm{Ce}$ ratios in the pre-eruptive rhyolitic and the parental dacitic melts (Table 2) are close to those of subduction zone magmas near the volcanic front (Noll et al., 1996) where the possible interaction with the mantle wedge is expected to be minimal (McCulloch and Gamble, 1991).

The calculated $\mathrm{Pb} / \mathrm{Ce}$ and $\mathrm{As} / \mathrm{Ce}$ ratios in the oceanic slab and adakitic magmas (Table 3) suggest that, in addition to the slab, a fluid phase is likely to be responsible for the observed ore metal enrichment in the adakitic magmas. Indeed, the enrichment in $\mathrm{Pb}, \mathrm{Mo}, \mathrm{As}$ and $\mathrm{Sb}$ relative to $\mathrm{Ce}$ in the melts is likely to be a result of fluid-melt fractionation rather than crystalmelt fractionation (Noll et al., 1996). $\mathrm{Pb}$ and $\mathrm{Cu}$ enrichment relative to $\mathrm{REE}$ and $\mathrm{Y}$ is documented in slab-derived fluid during dehydration of subducting oceanic crust (e.g., Kogiso et al., 1997). Such a fluid derived from the dehydrated oceanic slab is likely to be important in the ore metal enrichment of the adakitic magmas. Because of the highly oxidizing conditions during adakite magma differentiation which destabilize sulfide phases, these metals are easily mobilized likely in the form of chloride complexes by Cl-bearing aqueous fluids (Keppler and Wyllie, 1991, Stolper and Newman, 1994, Keppler, 1996, Frank et al., 2002 and Pokrovski et al., 2005) derived from descending, dehydrated oceanic crust. Moreover, the $\mathrm{SO}_{2}$ ligand which becomes the dominant sulfur species at the expense of $\mathrm{H}_{2} \mathrm{~S}$ in the oxidized fluid might also form soluble complexes with chalcophile metals and, thus, further facilitate their mobility.

To estimate major and trace element compositions of the slab-derived fluid, we used the available data on trace element partitioning between slab and fluid, and eclogite mineral and fluid (Table 3). The estimated composition of the slab-derived fluid is enriched in $\mathrm{Pb}$ and alkaline earth elements relative to REE (Fig. 3). The calculated contents of $\mathrm{Sr}, \mathrm{Au}, \mathrm{Cu}, \mathrm{Zn}, \mathrm{Pb}$ and $\mathrm{Mo}$ in the slab-derived fluid overlap those of the aqueous fluid in equilibrium with the Mt. Pinatubo dacitic magma at high-pressure conditions (Fig. 4, Table 2 and Table 3). These findings support the idea that the saturation of the Mt. Pinatubo adakitic melt with metalbearing fluid promoted the enrichment of the adakitic magmas in gold and associated metals and $\mathrm{H}_{2} \mathrm{O}$ (Table 2). ${ }^{87} \mathrm{Sr} /{ }^{87} \mathrm{Sr}$ ratios approaching 0.704 in the Mt. Pinatubo adakitic magmas (e.g., Bernard et al., 1996) are typical of the oceanic slab (McCulloch and Gamble, 1991), and their high $\mathrm{Sr} / \mathrm{Y}$ ratio (between 45 and 48) could indicate that the chemistry of these magmas was controlled by supercritical fluids rich in $\mathrm{Sr}$ and derived directly from the dehydrated oceanic slab. 
Table 3. : Major and trace element compositions of subducting oceanic slab (MORB and sediments), slab-derived fluid, and adakite magma

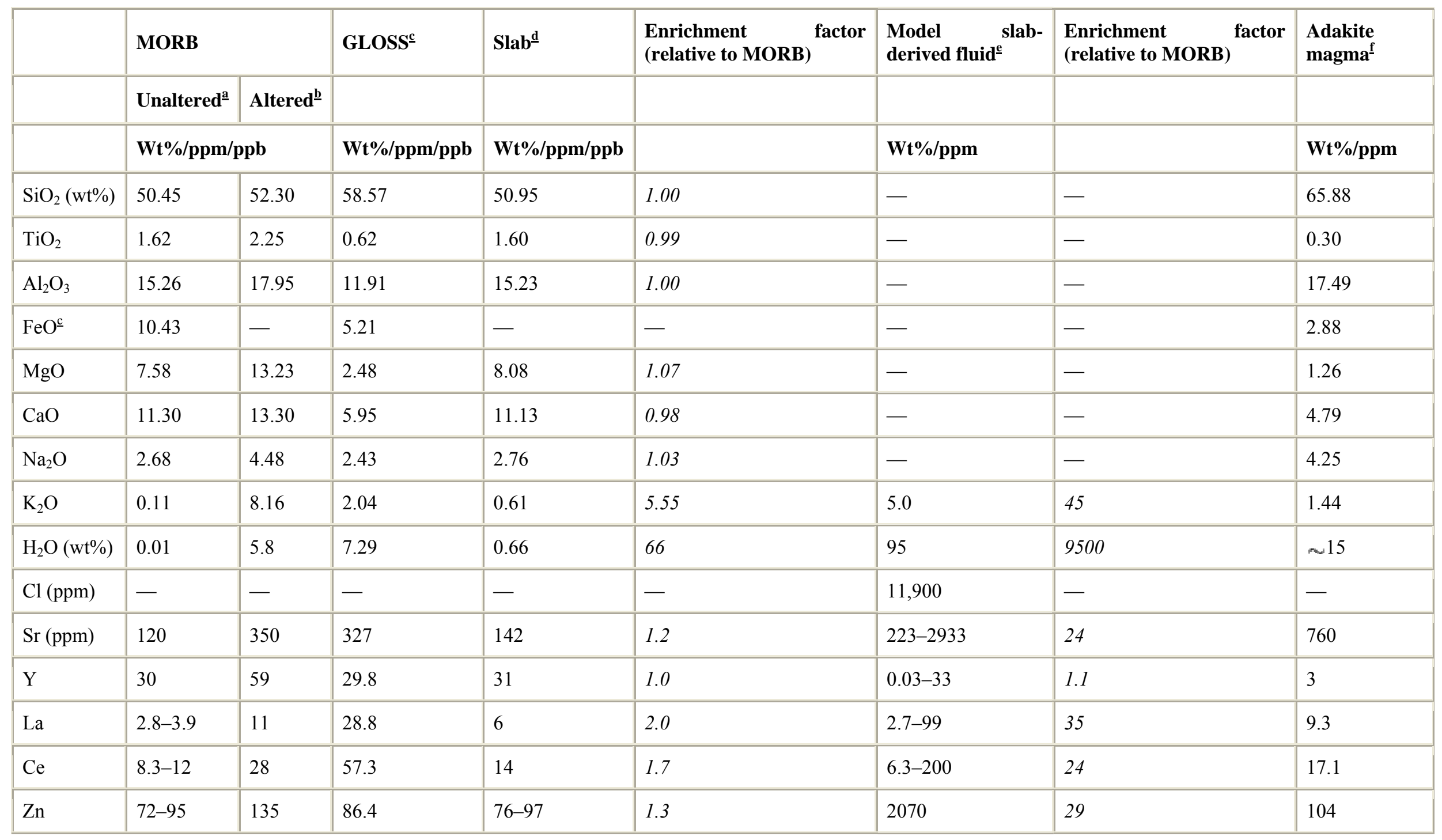




\begin{tabular}{|c|c|c|c|c|c|c|c|c|}
\hline & \multicolumn{2}{|l|}{ MORB } & \multirow{3}{*}{$\begin{array}{l}\text { GLOSS }^{\mathrm{c}} \\
\mathbf{W t} \% / \mathbf{p p m} / \mathbf{p p b}\end{array}$} & \multirow{3}{*}{\begin{tabular}{|l|} 
Slab $^{\mathrm{d}}$ \\
Wt\%/ppm/ppb \\
\end{tabular}} & \multirow{3}{*}{$\begin{array}{l}\text { Enrichment factor } \\
\text { (relative to MORB) }\end{array}$} & \multirow{3}{*}{$\begin{array}{l}\begin{array}{l}\text { Model slab- } \\
\text { derived fluid }^{\mathrm{e}}\end{array} \\
\text { Wt\%/ppm }\end{array}$} & \multirow{3}{*}{\begin{tabular}{|l|l|}
$\begin{array}{l}\text { Enrichment factor } \\
\text { (relative to MORB) }\end{array}$ \\
\\
\end{tabular}} & \multirow{3}{*}{\begin{tabular}{|l|}
$\begin{array}{l}\text { Adakite } \\
\text { magma }^{\text {f }}\end{array}$ \\
Wt\%/ppm \\
\end{tabular}} \\
\hline & Unaltered $^{\mathbf{a}}$ & Altered $^{\underline{b}}$ & & & & & & \\
\hline & \multicolumn{2}{|c|}{ Wt\%/ppm/ppb } & & & & & & \\
\hline $\mathrm{Cu}$ & 75 & 295 & 75.0 & 86 & 1.2 & 1996 & 27 & 171 \\
\hline Mo & 2.1 & 12 & 0.6 & 3 & 1.4 & 0.44 & 0.2 & 7 \\
\hline $\mathrm{Pb}$ & $0.4-0.7$ & 55 & 19.9 & 4 & 10 & $16-400$ & 1000 & 33 \\
\hline As & 2 & 5 & 10.3 & 2.6 & 1.3 & 7.3 & 3.7 & 11 \\
\hline $\mathrm{Sb}(\mathrm{ppb})$ & $17-74$ & 7259 & 400 & 600 & 35 & 450 & 26 & 1800 \\
\hline $\mathrm{Au}(\mathrm{ppb})$ & $3.2-8.7$ & $0.2-0.7$ & $1.1-3.1$ & $1.1-4.1$ & 1.3 & $\sim 200$ & 62 & - \\
\hline $\mathrm{Sr} / \mathrm{Y}$ & 4 & 6 & 11 & 5 & - & 97,766 & - & 253 \\
\hline $\mathrm{Pb} / \mathrm{Ce}$ & $0.03-0.06$ & 2 & 0.3 & 0.3 & - & 63 & - & 1.9 \\
\hline $\mathrm{Mo} / \mathrm{Ce}$ & $0.18-0.25$ & 0.4 & 0.01 & 0.18 & - & 0.21 & - & 0.4 \\
\hline $\mathrm{As} / \mathrm{Ce}$ & $0.17-0.24$ & 0.18 & 0.07 & 0.16 & - & 3.5 & - & 0.6 \\
\hline
\end{tabular}

${ }^{\mathrm{a}}$ Average unaltered MORB data are from: Sun et al. (2004) for Au; Hertogen et al. (1980) for $\mathrm{Zn}$, Sb and $\mathrm{Au}$; Doe (1994) for Cu, Pb; Jochum and Verma (1996) for Sb, Pb, $\mathrm{Sr}, \quad \mathrm{Y}$ and LREE; Hofmann (1988) for major elements, La, Ce; Onishi and Sandell (1955) for As; Au and Sb are in ppb. ${ }^{\mathrm{b}}$ Maximal contents of major and trace elements in altered MORB and MORB glasses are after Alt and Emmermann, 1983, Frey et al., 1974, Humphris and Thompson, 1978a, Humphris and Thompson, 1978b and Staudigel et al., 1981 for major elements, Cu, Sr, Y, LREE and Pb; Jochum and Verma (1996) for La, Ce, Pr, Pb and Sb; Pichler et al. (1991) for Mo, Sr; Böhlke et al. (1981) for $\mathrm{H}_{2} \mathrm{O}, \mathrm{Cu}$ and $\mathrm{Zn}$; Onishi and Sandell (1955) for As; Nesbitt et al. (1987) for Au; Au and Sb in ppb.

${ }^{\mathrm{c}}$ The global subducting sediment composition (GLOSS) is after Plank and Langmuir (1998); model sediment data for As, Sb and Mo (in ppm) are from Noll et al., 1996 and Onishi and Sandell, 1955; Au (in ppb) is al. (1973).

${ }^{\mathrm{d}}$ The slab composition is estimated as $5 \mathrm{wt} \%$ sediment (GLOSS), $5 \mathrm{wt} \%$ altered MORB and $90 \mathrm{wt} \%$ unaltered MORB; enrichment factors is maximal ratios of slab concentrations to those of ${ }^{\mathrm{e}}$ Composition of slab-derived fluid (or supercritical fluid) is after Tatsumi and Kogiso (1997) for $\mathrm{Cl}, \mathrm{H}_{2} \mathrm{O}, \mathrm{Na}_{2} \mathrm{O}, \mathrm{K}_{2} \mathrm{O}, \mathrm{Sr}, \mathrm{Y}$ and $\mathrm{Pb}$; the fluid composition is calculated after slab composition and slab/fluid partitioning for $\mathrm{Pb}, \mathrm{Sr}, \mathrm{Y}$, La and Ce of Ayers (1998) and eclogite/fluid partitioning of Brenan et al. (1995) for $\mathrm{Pb}$ and $\mathrm{Sr}$; $\mathrm{H}_{2} \mathrm{O}-$-rich component 
of Stolper and Newman (1994) for $\mathrm{Cl}, \mathrm{Cu}, \mathrm{Zn}$ and $\mathrm{Pb}$ is also used; $\mathrm{Au}$ (ppb) contents in amphibolite-derived fluid are after Loucks and Mavrogenes (1999); As, Sb, Mo, $\mathrm{Mo} / \mathrm{Ce}, \mathrm{As} / \mathrm{Ce}$ and $\mathrm{Sb} / \mathrm{Ce}$ are after Noll et al. (1996); enrichment factors is maximal ratios of slab-derived fluid concentrations to those of fresh MORB.

${ }^{\mathrm{f}}$ Adakite magma composition is major and trace element ( $\mathrm{La}, \mathrm{Ce}, \mathrm{Sr}$ and $\mathrm{Y}$ ) composition of Cenozoic adakites after Drummond and Defant (1990) and $\mathrm{H}_{2} \mathrm{O}$ content is after Prouteau et al. (1999); Chalcophile element contens are average of those of young adakite-like magmas related to ore deposits (González-Partida et al., 2003 and Qu et al., 2004). 


\subsection{Concluding remarks: Ore-forming potential of adakite magmatism}

Oxidizing conditions above $\mathrm{NNO}+1$ during the high-pressure and pre-eruptive crystallization stages of the Mt. Pinatubo magma caused the predominance of sulfate over sulfide in the hydrous magmas. In turn, this limited the segregation of chalcopyrite and promoted $\mathrm{Au}$ - and associated $\mathrm{Cu}, \mathrm{Zn}, \mathrm{Pb}$, As and Sb-enrichment in the residual adakite melts. A limited amount of titanomagnetite crystallized under the Mt. Pinatubo high-pressure conditions (Prouteau and Scaillet, 2003), explaining why the adakite magma was finally enriched in Zn and Mo (e.g., Hedenquist and Lowenstern, 1994).

The Mt. Pinatubo hydrous adakite melts were fluid-saturated and had peraluminous compositions with $\mathrm{A} / \mathrm{NK}>1.0$. Other high- $\mathrm{Al}$ adakitic magmas related to $\mathrm{Au} / \mathrm{Cu}$ and $\mathrm{Cu} / \mathrm{Mo}$ mineralization are peraluminous as well. Most of these magmas contain early phenocrysts of hydrous minerals such as hornblende and biotite, implying early magma saturation with an aqueous fluid (Sajona and Maury, 1998). The peraluminous composition of the adakitic magmas favors the concentration of metal into an aqueous fluid phase. Although the soft chalcophile metals $(\mathrm{Au}, \mathrm{Cu})$ are known to form very stable complexes with reduced sulfur ligands $\left(\mathrm{SO}_{2}, \mathrm{H}_{2} \mathrm{~S}\right)$, the effective scavenging of sulfur from melt and fluid due to abundant anhydrite crystallization rendered sulfide complexes less abundant than those with chloride which was present at much higher concentrations. Thus, the aqueous chloride-rich fluids liberated upon magma differentiation could have efficiently extracted hundreds of tones of metals with the potential to create a hydrothermal ore deposit (auriferous porphyry copper deposit or epithermal gold veins), provided that the residual magma was not erupted and that the necessary conditions for subsequent ore deposition prevailed (e.g., Loucks and Mavrogenes, 1999).

In the Philippines adakitic magmas related to $\mathrm{Au} / \mathrm{Cu}$ deposits are located in the volcanic fronts of the subducting zones. The petrogenesis of the adakitic magmas was largely controlled by fluid-present melting of the subducting slab; and their location in the volcanic front is likely due to liberation of slab-derived aqueous fluids. Thus, the Mt. Pinatubo adakitic magmas are enriched in $\mathrm{H}_{2} \mathrm{O}, \mathrm{Au}, \mathrm{Cu}, \mathrm{Zn}, \mathrm{Pb}, \mathrm{Mo}, \mathrm{As}, \mathrm{Sb}, \mathrm{Sr}$, LREE and $\mathrm{Cl}$ due to an important contribution of deep flab-derived fluids. 


\section{Acknowledgments}

G.S. Pokrovski is thanked for assistance and discussions. We thank M. Cathelineau, C. Marignac, E.H. Oelkers, G. Prouteau, F. Poitrasson, S. Salvi for discussions and insightful suggestions which significantly improved the manuscript. We thank M.R. Frank, J. Hanley and R.J. Goldfarb for constructive reviews and very helpful comments. The careful editorial handling of Edward M. Ripley helped clarify the manuscript. We thank Fabienne de Parseval for sample preparation for EMPA, SIMS and LA-ICP-MS. Ph. de Parseval, Th. Aigouy, O. Appelt and I. Schäpan are thanked for assistance during EMPA and SIMS analyses at LMTG and GFZ. We thank J. Koepke of the University of Hannover for preparing the hydrated glass samples used for our SIMS calibrations. This work has been supported by a post-doctoral fellowship from the French Ministry of Scientific Researches (A.B., 2005) and by CNRS grant through the GDR "Transmet" (A.B. and M.P. 2002-2005).

\section{References}

Alt and Emmermann, 1983 Alt J.C., Emmermann R., 1983, Geochemistry of Hydrothermally Altered Basalts: Deep Sea Drilling Project Hole 504B, Leg 83, Init. Rep. DSDP, Washington, DC, pp. 249-262.

Andersen and Lindsley, 1988 D.J. Andersen and D.H. Lindsley, Internally consistent solution model for Fe-Mg-Mn-Ti oxides, Am. Mineral. 73 (1988), pp. 714-726.

Aries et al., 2000 S. Aries, M. Valladon, M.B. Polvé and B. Dupré, A routine method for oxide and hydroxide interference corrections in ICP-MS chemical analysis of environmental and geological samples, Geostand. Newslett. 24 (2000), pp. 19-31.

Aries et al., 2001 S. Aries, M. Motelica-Heino, R. Freydier, Th. Grezes and M. Polvé, Direct determination of lead isotope ratios by laser ablation-inductively coupled plasma-quadrupole mass spectrometry in lake sediment samples, Geostand. Newslett. 25 (2001), pp. 387-398.

Ayers, 1998 J.C. Ayers, Trace element modelling of aqueous fluid-peridotite interaction in the mantle wedge of subduction zones, Contrib. Mineral. Petrol. 132 (1998), pp. 390-404.

Bernard et al., 1991 A. Bernard, D. Demaiffe, N. Mattielli and R.S. Punongbayan, Anhydritebearing pumices from mount pinatubo: further evidence for the existence of sulphur-rich silicic magmas, Nature 354 (1991), pp. 139-140.

Bernard et al., 1996 A. Bernard, U. Knittel, B. Weber, D. Weis, A. Albrecht, K. Hattori, J. Klein and D. Oles, Petrology and geochemistry of the 1991 eruption products of Mount Pinatubo. In: Ch.G. Newhall and R.S. Punongbayan, Editors, Fire and Mud. Eruptions and Lahars of Mount Pinatubo, Philippines, University of Washington Press, Seattle (1996), pp. 767-798.

Böhlke et al., 1981 J.K. Böhlke, J. Honnorez, B.-M. Honnorez-Guerstein, K. Muehlenbachs and N. Petersen, Heterogeneous alteration of the upper oceanic crust: correlation of rock 
chemistry, magnetic properties, and $\mathrm{O}$ isotope ratios with alteration patterns in basalts from site 396B, DSDP, J. Geophys. Res. 86 (1981) (B9), pp. 7935-7950.

Borisova et al., 2005 A.Yu. Borisova, M. Pichavant, J.-M. Beny, O. Rouer and J. Pronost, Constraints on dacite magma degassing and regime of the June 15, 1991, climactic eruption of Mount Pinatubo (Philippines): new data on melt and crystal inclusions in quartz, J. Volcanol. Geotherm. Res. 145 (2005), pp. 35-67.

Brenan et al., 1995 J.M. Brenan, H.F. Shaw, F.J. Ryerson and D.L. Phinney, Mineral-aqueous fluid partitioning of trace elements at $900{ }^{\circ} \mathrm{C}$ and $2.0 \mathrm{GPa}$ : constraints on the trace element chemistry of mantle and deep crustal fluids, Geochim. Cosmochim. Acta 59 (1995), pp. 33313350 .

Candela, 1989 P.A. Candela, Ore deposits associated with magmas. In: J.A. Whitney and A.J. Naldrett, Editors, Rev. Econ. Geol. vol. 4, Soc. Econ. Geol., Littleton, Colorado (1989), pp. 202-232.

Candela and Holland, 1984 P.A. Candela and H.D. Holland, The partitioning of copper and molybdenum between silicate melts and aqueous fluids, Geochim. Cosmochim. Acta 48 (1984), pp. 373-380. Abstract

Carroll and Rutherford, 1987 M.R. Carroll and M.J. Rutherford, The stability of igneous anhydrite: experimental results and implications for sulfur behaviour in the 1982 El Chichon trachyandesite and other evolved magmas, J. Petrol. 28 (1987), pp. 781-801.

Carron and LaGache, 1980 J.P. Carron and M. LaGache, Etude expérimentale du fractionnement des éléments $\mathrm{Rb}, \mathrm{Cs}, \mathrm{Sr}$ et $\mathrm{Ba}$ entre feldspaths alcalins, solutions hydrothermales et liquides silicates dans le système Q.Ab.Or. $\mathrm{H}_{2} \mathrm{O}$ à 2 kbar entre 700 et $800{ }^{\circ} \mathrm{C}$, Bull. Miner. 703 (1980), pp. 571-578.

Clemente et al., 2004 B. Clemente, B. Scaillet and M. Pichavant, The solubility of sulphur in hydrous rhyolitic melts, J. Petrol. 45 (2004), pp. 2171-2196.

Connors et al., 1993 K.A. Connors, D.C. Noble, S.D. Bussey and S.I. Weiss, Initial gold contents of silicic volcanic rocks: bearing on the behavior of gold in magmatic system, Geology 21 (1993), pp. 937-940.

Crocket et al., 1973 J.H. Crocket, J.D. Macdougall and R.C. Harriss, Gold, palladium and iridium in marine sediments, Geochim. Cosmochim. Acta 37 (1973), pp. 2547-2556.

Defant and Drummond, 1990 M.J. Defant and M.S. Drummond, Derivation of some modern arc magmas by melting of young subducted lithosphere, Nature 347 (1990), pp. 662-665.

Drummond and Defant, 1990 M.S. Drummond and M.J. Defant, A model for trondhjemitetonalite-dacite genesis and crustal growth via slab melting: Archean to modern comparisons, J. Geophys. Res. 95 (1990) (B13), pp. 21503-21521.

Doe, 1994 B.R. Doe, Zinc, copper, and lead in mid-ocean ridge basalts and the source rock control on $\mathrm{Zn} / \mathrm{Pb}$ in ocean-ridge hydrothermal deposits, Geochim. Cosmochim. Acta 58 (1994), pp. 2215-2223. 
Fournelle et al., 1996 J. Fournelle, R. Carmody and A.S. Daag, Anhydrite-bearing pumices from the June 15, 1991, eruption of Mt. Pinatubo: geochemistry, mineralogy, and petrology. In: Ch.G. Newhall and R.S. Punongbayan, Editors, Fire and Mud. Eruptions and Lahars of Mt. Pinatubo, Philippines, University of Washington Press, Seattle (1996), pp. 845-863.

Frank et al., 2002 M.R. Frank, P.A. Candela, P.M. Piccoli and M.D. Glascock, Gold solubility, speciation, and partitioning as a function of $\mathrm{HCl}$ in the brine-silicate melt-metallic gold system at $800^{\circ} \mathrm{C}$ and $100 \mathrm{MPa}$, Geochim. Cosmochim. Acta 66 (2002), pp. 3719-3732.

Frey et al., 1974 F.A. Frey, W.B. Bryan and G. Thompson, Atlantic Ocean floor: geochemistry and petrology of basalts from legs 2 and 3 of the Deep-Sea Drilling Project, J, Geophys. Res. 79 (1974), pp. 5507-5527.

Gerlach et al., 1996 T.M. Gerlach, H.R. Westrich and R.B. Symonds, Pre-eruption vapor in magma of the climactic Mount Pinatubo eruption: Source of the giant stratospheric sulfur dioxide cloud. In: Ch.G. Newhall and R.S. Punongbayan, Editors, Fire and Mud. Eruptions and Lahars of Mount Pinatubo, Philippines, University of Washington Press, Seattle (1996), pp. 415-434.

Goff et al., 1994 F. Goff, J.A. Stimac, A.C.L. Larocque, J.B. Hulen, G.M. McMurtry, A.I. Adams, M.A. Roldán, P.E. Trujillo, D. Counce Jr., S.J. Chipera and D. Mann, Gold degassing and deposition at Galeras Volcano, Colombia, GSA Today 4 (1994), pp. 243-247.

Goldschmidt, 1954 V.M. Goldschmidt, Geochemistry. In: A. Muir, Editor, Clarendon Press, Oxford (1954), p. 730.

González-Partida et al., 2003 E. González-Partida, G. Levresse, A. Carrillo-Chávez, A. Cheilletz, D. Gasquet and D. Jones, Paleocene adakite $\mathrm{Au}-\mathrm{Fe}$ bearing rocks, Mezcala, Mexico: evidence from geochemical characteristics, J. Geochem. Explor. 80 (2003), pp. 2540 .

Hanley et al., 2005 J.J. Hanley, T. Pettke, J.E. Mungall and E.T.C. Spooner, The solubility of platinum and gold in $\mathrm{NaCl}$ brines at $1.5 \mathrm{kbar}, 600$ to $800^{\circ} \mathrm{C}$ : a laser ablation ICP-MS pilot study of synthetic fluid inclusions, Geochim. Cosmochim. Acta 69 (2005), pp. 2593-2611.

Hattori, 1993 K. Hattori, High-sulfur magma, a product of fluid discharge from underlying mafic magma: evidence from Mount Pinatubo, Philippines, Geology 21 (1993), pp. 10831086 .

Hattori, 1996 K. Hattori, Occurrence and origin of sulfide and sulfate in the $1991 \mathrm{Mt}$. Pinatubo Eruption Products. In: Ch.G. Newhall and R.S. Punongbayan, Editors, Fire and Mud. Eruptions and Lahars of Mt. Pinatubo, Philippines, University of Washington Press, Seattle (1996), pp. 807-824.

Hedenquist and Lowenstern, 1994 J.W. Hedenquist and J.B. Lowenstern, The role of magmas in the formation of hydrothermal ore deposits, Nature 370 (1994), pp. 519-527.

Hertogen et al., 1980 J. Hertogen, M.-J. Janssen and H. Palme, Trace elements in ocean ridge basalt glasses: Implications for fractionations during mantle evolution and petrogenesis, Geochim. Cosmochim. Acta 44 (1980), pp. 2125-2143. 
Hervig, 1996 R.L. Hervig, Analyses of geological materials for boron by secondary ion mass spectrometry. In: E.S. Grew and L.M. Anovitz, Editors, Reviews in Mineralogy 33, Mineral Soc. Am., Washington, DC (1996), pp. 789-803.

Hofmann, 1988 A.W. Hofmann, Chemical differentiation of the Earth: the relationship between mantle, continental crust, and oceanic crust, Earth Planet. Sci. Lett. 90 (1988), pp. 297-314.

Holland, 1972 H.D. Holland, Granites, solutions, and base metal deposits, Econom. Geol. 67 (1972), pp. 281-301.

Hoosain and Baker, 1996 L. Hoosain and D.R. Baker, Solubility of gold in two granitic melts and its partitioning between sulfides and melt, GAC-MAC Program Abstr. 21 (1996), pp. A45 .

Humphris and Thompson, 1978a S.E. Humphris and G. Thompson, Hydrothermal alteration of oceanic basalts by seawater, Geochim. Cosmochim. Acta 42 (1978), pp. 107-125.

Humphris and Thompson, 1978b S.E. Humphris and G. Thompson, Alteration of the oceanic crust: processes and timing, Earth Planet, Sci. Lett. 52 (1978), pp. 311-327.

Ihinger et al., 1994 P.D. Ihinger, R.L. Hervig and P.F.M.J. McMillan, Analytical methods for volatiles in glasses. In: M.R. Carroll and J.R. Holloway, Editors, Volatiles in Magmas, Rev. Mineral. vol. 30, Mineral. Soc. of Am., Washington, DC (1994), pp. 67-112.

Imai et al., 1993 A. Imai, E.L. Listanco and T. Fujii, Petrologic and sulfur isotopic significance of highly oxidizing and sulfur-rich magma of Mt. Pinatubo, Philippines, Geology 21 (1993), pp. 699-702.

Imai et al., 1996 A. Imai, E.L. Listanco and T. Fujii, Highly oxidizing and sulfur-rich dacitic magma of Mount Pinatubo: implication for metallogenesis of porphyry copper mineralization in the Western Luzon Arc. In: Ch.G. Newhall and R.S. Punongbayan, Editors, Fire and Mud. Eruptions and Lahars of Mount Pinatubo, Philippines, University of Washington Press, Seattle (1996), pp. 865-874.

Ito et al., 1983 E. Ito, D.M. Harris and A.T. Anderson Jr., Alteration of oceanic crust and geologic cycling of chlorine and water, Geochim. Cosmochim. Acta 47 (1983), pp. 16131624.

Jégo et al., 2004 Jégo S., Polvé M., De Parseval Ph., Maury R. 2004. Gold in Adakitic Magmas: Concentrations and Localisation within the Rocks. Reunion de Sciences de la Terre RSTGV-A-00283 (pdf.).

Jochum and Verma, 1996 K.P. Jochum and S.P. Verma, Extreme enrichment of Sb, Tl and other trace elements in altered MORB, Chem. Geol. 130 (1996), pp. 289-299.

Keppler, $1996 \mathrm{H}$. Keppler, Constraints from partitioning experiments on the composition of subduction-zone fluids, Nature 380 (1996), pp. 237-240. 
Keppler and Wyllie, 1991 H. Keppler and P.J. Wyllie, Partitioning of Cu, Sn, Mo, W, U, and Th between melt and aqueous fluid in the system haplogranite- $\mathrm{H}_{2} \mathrm{O}-\mathrm{HCl}$ and haplograbite$\mathrm{H}_{2} \mathrm{O}-\mathrm{HF}$, Contrib. Mineral. Petrol. 109 (1991), pp. 139-150.

Kogiso et al., 1997 T. Kogiso, Y. Tatsumi and S. Nakano, Trace element transport during dehydration processes in the subducted oceanic crust: 1. Experiments and implications for the origin of ocean island basalts, Earth Planet. Sci. Lett. 148 (1997), pp. 193-205.

Koepke and Behrens, 2001 J. Koepke and H. Behrens, Trace element diffusion in andesitic melts: an application of synchrotron X-ray fluorescence analysis, Geochim. Cosmochim. Acta 65 (2001), pp. 1481-1498.

London et al., 1988 D. London, R.L. Hervig and G.B. Morgan VI, Melt-vapor solubilities and elemental partitioning in peraluminous granite-pegmatite systems: experimental results with Macusani glass at $200 \mathrm{MPa}$, Contrib. Mineral. Petrol. 99 (1988), pp. 360-373.

Loucks and Mavrogenes, 1999 R.R. Loucks and J.A. Mavrogenes, Gold solubility in supercritical hydrothermal brines measured in synthetic fluid inclusions, Science 284 (1999), pp. 2159-2163.

Luhr and Melson, 1996 J.F. Luhr and W.G. Melson, Mineral and glass compositions in June 15, 1991, pumices: evidence for dynamic disequilibrium in the dacite of Mt. Pinatubo. In: Ch.G. Newhall and R.S. Punongbayan, Editors, Fire and Mud. Eruptions and Lahars of Mt. Pinatubo, Philippines, University of Washington Press, Seattle (1996), pp. 733-750.

Malihan, 1987 Malihan, T.D. 1987. The Gold-rich Dizon porhyry Copper Mine in the Western Central Luzon Island, Philippines: Its Geology and Tectonic Setting: Proceedings of the Pacific Rim Congress'87, Australian Institutes of Mining and Metallurgy. Parkville, Victoria, Australia, pp. 303-307.

McCulloch and Gamble, 1991 M.T. McCulloch and J.A. Gamble, Geochemical and geodynamical constraints on subduction zone magmatism, Earth Planet. Sci. Lett. 102 (1991), pp. 358-374.

Metrich and Rutherford, 1992 N. Metrich and M.J. Rutherford, Experimental study of chlorine behaviour in hydrous silicic melts, Geochim. Cosmochim. Acta 56 (1992), pp. 607616.

Mungall, 2002 J.E. Mungall, Roasting the mantle: slab melting and the genesis of major $\mathrm{Au}$ and $\mathrm{Au}$-rich $\mathrm{Cu}$ deposits, Geology 30 (2002), pp. 915-918.

Nesbitt et al., 1987 B.E. Nesbitt, R.M.St. Louis and K. Muehlenbachs, Distribution of gold in altered basalts of DSDP hole 504B, Can. J. Earth Sci. 24 (1987), pp. 201-209.

Noll et al., 1996 P.D. Noll Jr., H.E. Newsom, W.P. Leeman and J.G. Ryan, The role of hydrothermal fluids in the production of subduction zone magmas: Evidence from siderophile and chalcophile trace elements and boron, Geochim. Cosmochim. Acta 60 (1996), pp. 587611 . 
Onishi and Sandell, 1955 H. Onishi and E.B. Sandell, Geochemistry of arsenic, Geochim. Cosmochim. Acta 7 (1955), pp. 1-33.

Pallister et al., 1996 J.S. Pallister, R.P. Hoblitt, G.P. Meeker, R.J. Knight and D.F. Siems, Magma mixing at Mount Pinatubo: petrographic and chemical evidence from the 1991 deposits. In: Ch.G. Newhall and R.S. Punongbayan, Editors, Fire and Mud. Eruptions and Lahars of Mount Pinatubo, Philippines, University of Washington Press, Seattle (1996), pp. $687-732$.

Pasteris et al., 1996 J.D. Pasteris, B. Wopenka, A. Wang and T.N. Harris, Relative timing of fluid and anhydrite saturation: Another consideration in the sulfur budget of the Mount Pinatubo eruption. In: Ch.G. Newhall and R.S. Punongbayan, Editors, Fire and Mud. Eruptions and Lahars of Mount Pinatubo, Philippines, University of Washington Press, Seattle (1996), pp. 875-894.

Peacock et al., 1994 S.M. Peacock, T. Rushmer and A.B. Thompson, Partial melting of subducting oceanic crust, Earth Planet. Sci. Lett. 121 (1994), pp. 227-244.

Pearce et al., 1997 N.J.G. Pearce, W.T. Perkins, J.A. Westgate, M.P. Gorton, S.E. Jackson, C.R. Neal and S.P. Chenery, A compilations of new and published major and trace element data for NIST SRM 610 and NIST SRM 612 glass reference materials, Geostand. Newslett. 21 (1997), pp. 115-144.

Pichavant et al., 1987 Pichavant, M., Herrera, J.V., Boulmier, S., Briqueu, L., Joron, J-.L., Juteau, M., Marin, L., Michard, A., Sheppard, S.M., Treuil, M., Vernet, M., 1987. The macusani glasses, SE Peru: evidence of chemical fractionation in Peraluminous magmas. In: B.O. Mysen (eds.) Magmatic Processes: Physicochemical Principles, The Geochemical Society, Special Publications 1, pp. 359-373.

Pichavant et al., 1988 M. Pichavant, D.J. Kontak, L. Briqueu, J.V. Herrera and A.H. Clark, The miocene-pliocene Macusani Volcanics, SE Peru, Contrib. Mineral. Petrol. 100 (1988), pp. 325-338.

Pichler et al., 1991 T. Pichler, W.I. Ridley and E. Nelson, Low-temperature alteration of dredged volcanics from the Southern Chile Ridge: additional information about early stage of seafloor weathering, Mar. Geol. 159 (1991), pp. 155-177.

Plank and Langmuir, 1998 T. Plank and C.H. Langmuir, The chemical composition of subducting sediment and its consequences for the crust and mantle, Chem. Geol. 145 (1998), pp. 325-394.

Pokrovski et al., 2005 G.S. Pokrovski, J. Roux and J.-C. Harrichoury, Fluid density control on vapour-liquid partitioning of metals in hydrothermal systems, Geology 33 (2005), pp. 657660 .

Pokrovski et al., 2002 G.S. Pokrovski, I.V. Zakirov, J. Roux, D. Testemale, J.-L. Hazemann, A.Yu. Bychkov and G.V. Golikova, Experimental study of arsenic speciation in vapour phase to $500{ }^{\circ} \mathrm{C}$ : implications for As transport and fractionation in low-density crustal fluids and volcanic gases, Geochim. Cosmochim. Acta 66 (2002), pp. 3453-3480. 
Polvé et al., 2004 Polvé, M., de Parseval, P., Jégo S., Maury, R.C. 2004. Where is the Gold in Adakites: Preliminary Results from a EMPA-SIMS Study, 57-OSE-A1547, Joint AOGS 1st Annual Meeting and second APHW Conference, Abstracts vol.1, 166.

Polvé et al., 2003 Polvé, M., Maury, R. Joron, J.L., 2003. Slab Melting and the Origin of Gold in $\mathrm{Au}$ and $\mathrm{Au}-\mathrm{Cu}$ Deposits: Geochemical Clues from Recent Adakites. EGS meeting, Nice, Geophys. Res. Abstracts vol. 5, EGS-AGU-EUG Joint Assembly, EAE03-A-12068.

Prouteau et al., 1999 G. Prouteau, B. Scaillet, M. Pichavant and R.C. Maury, Fluid-present melting of ocean crust in subduction zones, Geology 27 (1999), pp. 1111-1114.

Prouteau and Scaillet, 2003 G. Prouteau and B. Scaillet, Experimental constraints on the origin of the 1991 Pinatubo dacite, J. Petrol. 44 (2003), pp. 2203-2241.

Qu et al., 2004 X. Qu, Z. Hou and Y. Li, Melt components derived from a subducted slab in late orogenic ore-bearing porhyries in the Gangdese copper belt, southern Tibetan plateau, Lithos 74 (2004), pp. 131-148.

Reich et al., 2003 M. Reich, M.A. Parada, C. Palacios, F. Schultz and B. Lehmann, Adakitelike signature of late Miocene intrusions at the Los Pelambres giant porhyry copper deposit in the Andes of Central Chile: metallogenic implications, Miner. Dep. 40 (2003), pp. 387-399.

Rutherford and Devine, 1996 M.J. Rutherford and J.D. Devine, Pre-eruption pressuretemperature conditions and volatiles in the 1991 dacitic magma of Mt. Pinatubo. In: Ch.G. Newhall and R.S. Punongbayan, Editors, Fire and Mud. Eruptions and Lahars of Mt. Pinatubo, Philippines, University of Washington Press, Seattle (1996), pp. 751-766.

Sajona and Maury, 1998 F.G. Sajona and R.C. Maury, Association of adakites with gold and copper mineralization in the Philippines, C.R. Acad. Sci. IIA Earth Planet. Sci. 326 (1998), pp. 27-34.

Scaillet et al., 1998 B. Scaillet, B. Clemente, B.W. Evans and M. Pichavant, Redox control of sulfur degassing in silicic magmas, J. Geophys. Res. 103 (1998) (B10), pp. 23937-23949.

Scaillet and Evans, 1999 B. Scaillet and B. Evans, The 15 June 1999 eruption of Mount Pinatubo. I Phase equilibria and pre-eruption $P-T-f_{\mathrm{O} 2}-f_{\mathrm{H} 2 \mathrm{O}}$ conditions of the dacite magma, $J$. Petrol. 40 (1999), pp. 381-411.

Silver et al., 1990 L.A. Silver, P.D. Ihinger and E. Stolper, The influence of bulk composition on the speciation of water in silicate glasses, Contrib. Mineral. Petrol. 104 (1990), pp. 142 162.

Sen and Dunn, 1994 C. Sen and T. Dunn, Dehydration melting of a basaltic composition amphibolite at 1.5 and $2.0 \mathrm{Gpa}$ : implications for the origin of adakites, Contrib. Mineral. Petrol. 117 (1994), pp. 394-409.

Sobolev and Chaussidon, 1996 A.V. Sobolev and M. Chaussidon, $\mathrm{H}_{2} \mathrm{O}$ concentrations in primary melts from supra-subduction zones and mid-ocean ridges: implications for $\mathrm{H}_{2} \mathrm{O}$ storage and recycling in the mantle, Earth Planet. Sci. Lett. 137 (1996), pp. 45-55. 
Staudigel et al., 1981 H. Staudigel, S.R. Hart and S.H. Richardson, Alteration of the oceanic crust: process and timing, Earth Planet. Sci. Lett. 52 (1981), pp. 311-327.

Stolper and Newman, 1994 E. Stolper and S. Newman, The role of water in the petrogenesis of Mariana trough magmas, Earth Planet. Sci. Lett. 121 (1994), pp. 293-325.

Sun and McDonough, 1989 Sun, S-.S., McDonough, W.M. 1989. Chemical and isotope systematics of oceanic basalts: implications for mantle compositions and processes. In: Saunders, A.D., Norry, M.J. (eds.). Magmatism in the Ocean Basins. Geological Society Special London Publication 42, pp. 313-345.

Sun et al., 2004 W.D. Sun, R.J. Arculus, V.S. Kamenetsky and R.A. Binns, Release of goldbearing fluids in convergent margin magmas prompted by magnetite crystallization, Nature 431 (2004), pp. 975-978.

Tatsumi and Kogiso, $1997 \mathrm{Y}$. Tatsumi and T. Kogiso, Trace element transport during dehydration processes in the subducted oceanic crust: 2. Origin of chemical and physical characteristics in arc magmatism, Earth Planet. Sci. Lett. 148 (1997), pp. 207-221.

Taylor et al., 1997 R.P. Taylor, S.E. Jackson, H.P. Longerich and J.D. Webster, In situ traceelement analysis of individual silicate melt inclusions by laser ablation microprobeinductively coupled plasma-mass spectrometry-LAM-ICP-MS, Geochim. Cosmochim. Acta 61 (1997), pp. 2559-2567.

Thiéblemont et al., 1997 D. Thiéblemont, G. Stein and J.-L. Lescuyer, Gisements épithermaux et porphyriques: la connexion adakite. Epithermal and porphyry deposits: the adakite connection. C.R. Acad. Sci. Paris, Sciences de la terre et des planètes, Earth Planet. Sci. 325 (1997), pp. 103-109.

Urabe, 1985 T. Urabe, Aluminous granite as a source magma of hydrothermal ore deposits: an experimental study, Econ. Geol. 80 (1985), pp. 148-157.

Watson, 1994 E.B. Watson, Diffusion in volatile-bearing magmas. In: M.R. Carroll and J.R. Holloway, Editors, Volatiles in Magmas, Rev. Mineral. vol. 30, Mineral. Soc. of Am., Washington, DC (1994), pp. 67-121.

Webster, 1992a J.D. Webster, Fluid-melt interactions involving Cl-rich granites: experimental study from 2 to 8 kbar, Geochim. Cosmochim. Acta 56 (1992), pp. 659-678.

Webster, 1992b J.D. Webster, Water solubility and chlorine partitioning in Cl-rich granitic systems: effect of melt composition at $2 \mathrm{kbar}$ and $800^{\circ} \mathrm{C}$, Geochim. Cosmochim. Acta 56 (1992), pp. 679-687.

Westrich and Gerlach, 1992 H.R. Westrich and T.M. Gerlach, Magmatic gas source for the stratosphere $\mathrm{SO}_{2}$ cloud from the June 15, 1991, eruption of Mount Pinatubo, Geology 20 (1992), pp. 867-870.

Whalen et al., 2004 J.B. Whalen, V.J. McNicoll, A.G. Galley and F.J. Longstaffe, Tectonic and metallogenic importance of an Archean composite high- and low-Al tonalite suite, Western Superior Province, Canada, Precambrian Res. 132 (2004), pp. 275-301. 
White et al., 1995 N.C. White, M.J. Leake, S.N. McCaughey and B.W. Parris, Epithermal gold deposits of the southwest Pacific, J. Geochem. Explor. 54 (1995), pp. 87-136.

Wiedenbeck et al., 2001 Wiedenbeck, M., Rocholl, A., Koepke, J. 2001. Water-A Source of Systematic Error in Quantitative SIMS Analyses of Hydrous Glasses. 11th Annual V.M. Goldschmidt Conference, Hot Spring, Virginia, USA, 3604.

Wood and Samson, 1998 Wood, S.A., Samson, I.M., 1998. Solubility of ore minerals and complexation of ore metals in hydrothermal solutions. In: Richrards, J.P., Larson, P.B. (Eds.), Techniques in Hydrothermal Ore Deposits Geology. Review in Economic Geology 10, Society of Economic Geologists, inc. p. 255. 